\title{
Upward nitrate transport by phytoplankton in oceanic waters: balancing nutrient budgets in oligotrophic seas
}

In oceanic subtropical gyres, primary producers are numerically dominated by small (1-5 $\mu \mathrm{m}$ diameter) pro- and eukaryotic cells that primarily utilize recycled nutrients produced by rapid grazing turnover in a highly efficient microbial loop. Continuous losses of nitrogen $(\mathrm{N})$ to depth by sinking, either as single cells, aggregates or fecal pellets, are balanced by both nitrate inputs at the base of the euphotic zone and $\mathrm{N}_{2}$-fixation. This input of new $\mathrm{N}$ to balance export losses (the biological pump) is a fundamental aspect of $\mathrm{N}$ cycling and central to understanding carbon fluxes in the ocean. In the Pacific Ocean, detailed $\mathrm{N}$ budgets at the time-series station HOT require upward transport of nitrate from the nutricline $(80-100 \mathrm{~m})$ into the surface layer ( 0-40 m) to balance productivity and export needs. However, concentration gradients are negligible and cannot support the fluxes. Physical processes can inject nitrate into the base of the euphotic zone, but the mechanisms for transporting this nitrate into the surface layer across many 10 s of $m$ in highly stratified systems are unknown. In these seas, vertical migration by the very largest $10^{2}-10^{3} \mu \mathrm{m}$ diameter) phytoplankton is common as a survival strategy to obtain $\mathrm{N}$ from sub-euphotic zone depths. This vertical migration is driven by buoyancy changes rather than by flagellated movement and can provide upward $\mathrm{N}$ transport as nitrate (mM concentrations) in the cells. However, the contribution of vertical migration to nitrate transport has been difficult to quantify over the required basin scales. In this study, we use towed optical systems and isotopic tracers to show that migrating diatom (Rhizosolenia) mats are widespread in the N. Pacific Ocean from $140^{\circ} \mathrm{W}$ to $175^{\circ} \mathrm{E}$ and together with other migrating phytoplankton (Ethmodiscus, Halosphaera, Pyrocystis, and solitary Rhizosolenia) can mediate time-averaged transport of $\mathrm{N}\left(235 \mu \mathrm{mol} \mathrm{N} \mathrm{m} \mathrm{m}^{-2} \mathrm{~d}^{-1}\right)$ equivalent to eddy nitrate injections $\left(242 \mu \mathrm{mol} \mathrm{NO}_{3}^{-} \mathrm{m}^{-2} \mathrm{~d}^{-1}\right)$. This

upward biotic transport can close $\mathrm{N}$ budgets in the upper $250 \mathrm{~m}$ of the central Pacific Ocean and together with diazotrophy creates a surface zone where biological nutrient inputs rather than physical processes dominate the new $\mathrm{N}$ flux. In addition to these numerically rare large PeerJ reviewing PDF | (v2014:01:1290:1:0:NEW 12 Feb 2014) 
migrators, there is evidence in the literature of ascending behavior in small phytoplankton that could contribute to upward flux as well. Although passive downward movement has dominated models of phytoplankton flux, there is now sufficient evidence to require a rethinking of this paradigm. Quantifying these fluxes is a challenge for the future and requires a reexamination of individual phytoplankton sinking rates as well as methods for capturing and enumerating ascending phytoplankton in the sea. 
2 Tracy A. Villareal ${ }^{1 *}$, Cynthia H. Pilskaln ${ }^{2}$, Joseph P. Montoya ${ }^{3}$, and Mark Dennett ${ }^{4}$

$3 \quad{ }^{1}$ Dept. of Marine Science and Marine Science Institute

4 The University of Texas, Austin

5750 Channel View Dr., Port Aransas, TX 78373 USA

$6 \quad{ }^{2}$ School for Marine Science and Technology (SMAST)

7 University of Massachusetts Dartmouth

8706 South Rodney French Blvd.

9 New Bedford, MA 02744 USA

$10 \quad{ }^{3}$ School of Biology

11 Georgia Institute of Technology

12 EST Building, 311 Ferst Drive

13 Atlanta GA 30332-0340 USA

$14{ }^{4}$ Woods Hole Oceanographic Institution

15 Woods Hole, MA 02543 USA

16 *Corresponding author: Tracy A. Villareal, Dept. of Marine Science and Marine Science Institute,

17 The University of Texas, Austin, 750 Channel View Dr., Port Aransas, TX 78373 USA

18 telephone: 361-749-6732, email: tracyv@ austin.utexas.edu 
Introduction

Nitrogen $(\mathrm{N})$ in the euphotic zone of the open sea has long been recognized to partition into two distinct pools of availability (Dugdale \& Goering 1967). New N represents introduction of $\mathrm{N}$ from outside the euphotic zone, either in the form of deep $\mathrm{NO}_{3}{ }^{-}, \mathrm{N}_{2}$-fixation, or atmospheric deposition, while regenerated $\mathrm{N}$ results from consumption and remineralization of dissolved or particulate N (Dugdale \& Goering 1967). While regenerated $\mathrm{N}$ dominates the total phytoplankton uptake, new $\mathrm{N}$ is critical to balance losses due to vertical fluxes and is linked to total system productivity (Eppley \& Peterson 1979). This has been expressed as the $f$ ratio where ' $f$ ' $=$ new/total $\mathrm{N}$ uptake and ranges from $0-1$. On longer time scales, new $\mathrm{N}$ input must balance sedimentary losses or the system will experience net losses of N (Eppley \& Peterson 1979). The surface waters of the oligotrophic open ocean are considered low ' $\mathrm{f}$ ' ratio environments: $\mathrm{N}$ and phosphate $(\mathrm{P})$ often occur at nanomolar $(\mathrm{nM})$ concentrations and ammonium is the dominant form taken up by phytoplankton (Lipschultz et al. 1996; Raimbault et al. 2008; Wu et al. 2000). The $f$ ratio increases in the light-limited lower depths of the euphotic zone due to the increased availability of nitrate at the nutricline, thus creating what has been recognized as a two-layered structure in the Sargasso Sea of near zero $f$ ratios in the mixed layer and elevated $\mathrm{f}$ ratios at or near the nutricline (Goldman 1988). This general pattern can be modified in regions of low iron input, where iron availability limits macronutrient consumption creating regions of high nutrientlow chlorophyll (HNLC) where low phytoplankton biomass persists despite elevated nutrient concentrations (de Baar et al. 2005). These HNLC zones tend to be in equatorial or high latitude regions (Boyd et al. 2007), leaving much of the central gyres in a macronutrient ( $\mathrm{N}$ or $\mathrm{P}$ ) limited state. Further complexity is introduced by euphotic zone nitrification. This process introduces nitrate internally rather than from exogenous sources (Ward 2008), can support the sustained $\mathrm{nM}$ nitrate concentrations ubiquitous in the gyres (Lipschultz et al. 2002) and substantially affects $f$ ratio calculation based on experimental ${ }^{15} \mathrm{NO}_{3}{ }^{-}$uptake (Clark et al. 2008). However, it is unclear whether it can provide the produce oxygen anomalies used as geochemical signatures (Jenkins \& Goldman 1985) to calculate export loss-based new production estimates.

The nutritionally-dilute environment creates strong evolutionary pressures on phytoplankton to decrease cell size (increased surface:volume ratios) as well as for mixotrophy to supplement photosynthesis (Beardall et al. 2009; Burkholder et al. 2008). In these strongly stratified environments, small prokaryotes are numerically dominant and often are specialists for exploiting either the light-rich, but nutrient limited, upper euphotic zone, or the region at the base of the euphotic zone where light becomes limiting and nutrients increase to micromolar concentrations (Malmstrom et al. 2010). In the Pacific Ocean, this transition zone is associated with the boundary between shallow and deep phytoplankton communities of diatoms, dinoflagellates and other phytoplankton resolved by light microscopy (Venrick 1988; Venrick 1990). Within the phytoplankton community is also a rare, but ubiquitous, flora of giant phytoplankton $\left(10^{2}-10^{3} \mu \mathrm{m}\right.$ diameter $)$ that avoids competition with the smaller phytoplankton by utilizing a vertical migration strategy (Villareal et al. 1993; Villareal \& Lipschultz 1995; Villareal et al. 1999b). Buoyancy regulation rather than flagellated motility allows these taxa to migrate 50-100+ $\mathrm{m}$ on a multiple-day time scale, acquire nitrate in sub-euphotic zone nitrate pools, and then return to the surface for photosynthesis (Villareal \& Lipschultz 1995; Villareal et al. 1996; Woods \& Villareal 2008). Such use of sub-nutricline derived nitrate to support carbon fixation at the surface defines the process as new production and injects phytoplankton behavior into discussions of nutrient biogeochemistry.

This group of oceanic phytoplankton has unique characteristics that identify them as vertical migrators. Rhizosolenia mats, the best-studied migrators, are associations of multiple species of the diatom genus Rhizosolenia that form intertwined aggregates (Fig. 1) from <1-30 cm in size (Villareal \& Carpenter 1989; Villareal et al. 1996) and can account for $26 \%$ of 
particulate Si formation in the N. Pacific (Shipe et al. 1999). First observed as "confervae" by Darwin (1860) in the South Atlantic, they occur in the N. Atlantic, N. Pacific and Indian Oceans (Villareal \& Carpenter 1989). The high biomass available in single Rhizosolenia mats has made them useful general models of vertical migration in non-flagellated phytoplankton with the caveat that almost all the physiological and compositional field data are from a limited region of the eastern central N. Pacific gyre. Initially described as possessing diazotrophic symbionts (Martinez et al. 1983), subsequent work found no evidence of diazotrophy (Villareal \& Carpenter 1989). Rhizosolenia mats possess $\mathrm{mM}$ internal $\mathrm{NO}_{3}{ }^{-}$pools (INP, Villareal et al. 1996), utilize $\mathrm{NO}_{3}{ }^{-}$ via nitrate reductase (Joseph et al. 1997), take up $\mathrm{NO}_{3}{ }^{-}$in the dark (Richardson et al. 1996), have a $\delta^{15} \mathrm{~N}$ (3-4 per mil) similar to the deep $\mathrm{NO}_{3}$ - pool (Villareal et al. 1993), ascend at up to $6.4 \mathrm{~m} \mathrm{~h}^{-1}$, become negatively buoyant under nutrient-depletion (Villareal et al. 1996), positively buoyant as they take up $\mathrm{NO}_{3}{ }^{-}$(Richardson et al. 1996), and are documented down to several hundred meters by direct ROV observations (Pilskaln et al. 2005). These characteristics indicate a life cycle vertical migration to deep nitrate pools similar to the non-motile dinoflagellate Pyrocystis (Ballek $\&$ Swift 1986), a migration notable for the greater distance $(\sim 100 \mathrm{~m})$ than that found in numerous flagellated taxa that migrate in the coastal zone (Kamykowski et al. 1978). Mat consumption by the vertically migrating lantern fish Ceratoscopelus warmingii (Robison 1984) provides at least one pathway for this $C$ to be sequestered in the deep sea although the fate of these diatom mats is perhaps the least understood aspect of their biology. Free-living Rhizosolenia and Ethmodiscus spp, the dinoflagellate Pyrocystis spp., and the prasinophyte Halosphaera spp. each possess some subset of characteristics such as (INP) nitrate pools and buoyancy control that suggest a similar life-history characteristic (Villareal \& Lipschultz 1995). Phytoplankton migrators are clearly transporting $\mathrm{N}$ (and presumably $\mathrm{P}$ ) upward, but the significance of the process in oceanic nutrient budgets has been hard to assess due to the limited geographic range of observations and abundance estimates (Emerson \& Hayward 1995; Johnson et al. 2010). This flora is endemic to all warm oceans, but their large size and relatively low numbers $\left(\sim 10^{0}-10^{2} \mathrm{~m}^{-3}\right)$ have made quantification uncommon as research efforts focused on the dominant nano and picoplankton that are 6-7 orders of magnitude more abundant.

Recent observations of isotopic anomalies in phytoplankton groups (Fawcett et al. 2011) and questions in nutrient budgets (Ascani et al. 2013; Johnson et al. 2010) have focused attention on phytoplankton sinking and ascent, and the role this may be playing in connecting deep nutrient pools with surface productivity. Nutrient budgets are key to constraining the "biological pump", the active removal of $\mathrm{CO}_{2}$ from the surface ocean to the deep sea by biological processes (DeVries et al. 2012). At a first approximation, use of upwelled nitrate leads to little net export of carbon (Lomas et al. 2013) since carbon dioxide is transported upward along with deep nitrate as it upwells due to advection or turbulence (Eppley \& Peterson 1979). This occurs as a result of the stoichiometric remineralization of organic material below the euphotic zone that releases $\mathrm{CO}_{2}$ proportional to the amount incorporated into the organic material at the surface. Both $\mathrm{N}$ and $\mathrm{P}$, in general, remineralize faster than carbon $(\mathrm{C})$ and decouple the stoichiometery of remineralization with depth. Remineralized $\mathrm{C}$ as $\mathrm{CO}_{2}$ is returned, in general, by the same processes that return nitrate to the euphotic zone. However, vertical migration and $\mathrm{N}$ transport by phytoplankton uncouples $\mathrm{N}$ and $\mathrm{C}$ transport. Unlike $\mathrm{NO}_{3}{ }^{-}$injection by physical mixing, there is no stoichiometric transport of DIC (dissolved inorganic carbon) associated with migrating phytoplankton; thus, this $\mathrm{N}$ use drives net drawdown of atmospheric $\mathrm{CO}_{2}{ }^{-}$from the euphotic zone. However, the importance of potential $\mathrm{CO}_{2}$ removal is dependent on unanswered questions surrounding the fate of these phytoplankton. In an analogous fashion, $\mathrm{N}_{2}$-fixation can support net carbon drawdown to depth since the $\mathrm{N}$ source $\left(\mathrm{N}_{2}\right.$ gas) is uncoupled from the deep $\mathrm{CO}_{2}$ pool (Eppley \& Peterson 1979). These general relationships are key elements in the biologically-mediated summertime 
116

117

118

119

120

121

122

123

124

125

126

127

128

129

130

131

132

133

134

135

136

137

138

139

140

141

142

143

144

145

146

147

148

149

150

151

152

153

154

155

156

157

158

159

160

161

162

163

drawdown of dissolved inorganic carbon in the oligotrophic gyres of both the N. Atlantic and N. Pacific (Keeling et al. 2004; Michaels et al. 1994).

Nitrogen budgets of the upper water column that quantify $\mathrm{NO}_{3}{ }^{-}$and $\mathrm{N}_{2}$-fixation inputs are therefore central to understanding the biogeochemical cycles of carbon in the euphotic zone and the remineralization region immediately below (often termed the twilight zone). At the long-term Hawai'i Ocean Time-series (HOT) station, annual nutrient budgets balance in the upper $250 \mathrm{~m}$ indicating that the $\mathrm{NO}_{3}{ }^{-}$component of the new $\mathrm{N}$ flux to support primary production and DIC drawdown is met by nitrate remineralized from sinking material in the upper $250 \mathrm{~m} . \mathrm{NO}_{3}{ }^{-}$ profiling technology coupled with long-term deployments of floats has highlighted the role that mesoscale eddies play in supplying $\mathrm{NO}_{3}{ }^{-}$to the base of the euphotic zone ( 80-100 m) (Ascani et al. 2013; Johnson et al. 2010; McGillicuddy et al. 2007; McGillicuddy \& Robinson 1997). However, $\mathrm{NO}_{3}{ }^{-}$concentrations rapidly decrease to $\mathrm{nM}$ levels immediately above the nutricline ( $\sim 80-100 \mathrm{~m})$ (Johnson et al. 2010). There is no mechanism to move $\mathrm{NO}_{3}{ }^{-}$along this negligible diffusion gradient into the upper water column where most community production occurs and $\mathrm{N}$ budgets require importation of $\mathrm{NO}_{3}^{-}$(Johnson et al. 2010). However, $<30 \mu \mathrm{m}$ diameter eukaryotes cells are found with $\delta^{15} \mathrm{~N}$ signatures of 4-5 per mil at 30-60 $\mathrm{m}$ in the Sargasso Sea, suggesting sub-euphotic zone $\mathrm{NO}_{3}{ }^{-}$is reaching these depths $40+\mathrm{m}$ above the nutricline (Fawcett et al. 2011).

Phytoplankton migrating across this gradient could provide a mechanism for transport via subsurface uptake and subsequent shallow excretion and/or remineralization (Singler \& Villareal 2005). In the eastern N. Pacific gyre, vertical migration is estimated to account for an average of $14 \%$ of new production with maximum values up to 59\% (Singler \& Villareal 2005; Villareal et al. 1999b). This transport has proven difficult to quantify on larger scales due to the challenges in enumerating and sampling these populations. The taxa involved, Rhizosolenia, Pyrocystis, Halosphaera, and Ethmodiscus spp. are sufficiently rare $\left(\sim 10^{0}-10^{2}\right.$ cells $\left.\mathrm{m}^{-3}\right)$ that large water samples or nets are required to enumerate them. Migrating diatom aggregates (Rhizosolenia mats, up to $30 \mathrm{~cm}$ in size) are fragile, requiring enumeration and hand-collection by SCUBA divers (Alldredge \& Silver 1982; Carpenter et al. 1977). Further complication arises from the observations that small mats $(\sim 1 \mathrm{~cm})$ dominating the Rhizosolenia mat biomass are visible only with sophisticated in-situ optical sensors that overcome both contrast problems and depth limitations for SCUBA (Villareal et al. 1999b). Moreover, the recognition that in the open ocean cells $<5 \mu \mathrm{m}$ in diameter dominate uptake and remineralization has shifted focus away from the largest size fractions towards the very smallest phytoplankton (Azam et al. 1983; Hagström et al. 1988; Karl et al. 2001; Li et al. 2011; Malone 1980; Maranon et al. 2001).

In this paper, we present a synthesis of both literature reports and direct observations to address the broader scope of vertical migration and nutrient transport in the open sea. For vertical migration to be relevant to oceanic $\mathrm{N}$ cycles, migrators must be widespread, episodically abundant at levels sufficient to support the required rates, and possess the chemical and isotopic signatures of deep nitrate pools. We present new data using in-situ optical systems complemented by isotopic and abundance data that spans much of the N. Pacific Ocean. Also presented is a synthesis that documents the widespread abundance of vertically migrating Rhizosolenia mats in the Pacific Ocean and their quantitative importance in transporting and releasing $\mathrm{N}$ as $\mathrm{NO}_{3-}$ within the upper $250 \mathrm{~m}$. We also compile published data on other migrating phytoplankton in the genera Rhizosolenia, Ethmodiscus, Halosphaera, and Pyrocystis, concluding that they constitute a ubiquitous and under-sampled aspect of nutrient cycling linked directly to the behavioral characteristics of the phytoplankton. Finally, we present literature evidence that ascending behavior in smaller phytoplankton is sufficiently widespread to require a reconsideration of the role of positive buoyancy in marine phytoplankton. 
164

165

166

167

168

169

170

171

172

173

174

175

176

177

178

179

180

181

182

183

184

185

186

187

188

189

190

191

192

193

194

195

196

197

198

199

200

201

202

203

204

205

206

207

208

209

210

211

Methods and Materials

Six research cruises between 1993-2003 examined Rhizosolenia mat biology along longitudinal transects at $\sim 28-31^{\circ} \mathrm{N}$ from California to Hawaii and Hawaii to west of Midway Island (Fig. 2). In all these cruises, Rhizosolenia mats were hand-collected by SCUBA divers (0$\sim 20 \mathrm{~m}$ ) as part of a multi-year effort to enumerate and characterize their biology. Briefly, divers collected mats in polymethylpentane plastic containers (250-500 $\mathrm{ml}$ volume), and returned them to the ship in a closed ice chest. Mat lysis (Martinez et al. 1983) was not observed. Mats were sorted into sinking and floating mats (Villareal et al. 1996), and then the entire mat was filtered onto pre-combusted GF/F filters followed by measurement of the concentration and isotopic composition of particulate organic $\mathrm{N}$ and $\mathrm{C}$ by continuous-flow isotope ratio mass spectrometry (CF-IRMS) (Montoya et al. 2002). Details of the analytical protocol for particulate analysis as well as standardization of these isotopic measurements can be found in Montoya et al (1996). Each analytical batch included peptone and acetanilide standards; the standard deviation of these standards was typically 0.05 per $\mathrm{ml}$. Mats collected by divers are typically $>2 \mu \mathrm{mol} \mathrm{N} \mathrm{mat}{ }^{-1}$ (Villareal et al. 1996). Samples in this range have an analytical precision of $\pm 0.2 \%$ (Montoya et al. 1996). Isotopic composition of $\mathrm{NO}_{3}{ }^{-}$was measured by CF-IRMS. $\mathrm{NO}_{3}{ }^{-}$was first reduced to NH4+ using Devarda's ally, followed by diffusion and trapping of the $\mathrm{NH}_{3}$ (Sigman et al. 1997). Divers enumerated mats in the upper $20 \mathrm{~m}$ using a $1 \mathrm{~m}^{2}$ frame equipped with a flow meter (Singler \& Villareal 2005; Villareal et al. 1996). The diver attached to the down line at 4-6 depths in the upper $20 \mathrm{~m}$ and swam the frame in a circle around the down line of approximately 9 $\mathrm{m}$ radius. The number of mats passing through the vertically oriented frame was recorded and normalized to the volume swept clear recorded on the flow meter. Integrated abundance used a trapezoidal integration to the maximum depth sampled $(\sim 20 \mathrm{~m})$ and is reported as mats $\mathrm{m}^{-2}$. In addition, abundance data were drawn from literature sources (Alldredge \& Silver 1982; Martinez et al. 1983) extending the time frame of diver-based observations to 26 years.

In 2003, a towed optical system (Video Plankton Recorder: VPR) was used to quantify abundance in the upper $150 \mathrm{~m}$. In this data set, we employed a recalibrated and tested VPR also used in our 1996 study (Pilskaln et al. 2005; Villareal et al. 1999b). The intersection of the strobe light volume and the camera's field of view represented an elongate trapezoid shape with a $7 \mathrm{~cm}$ depth of field and an individual image volume of 0.12 liter. A non-reparable malfunction of the VPR-interfaced CTD on our 2003 cruise made structural adjustments necessary in order to complete the VPR surveys which involved mounting the VPR (minus its CTD) to the CTD rosette. The fin section and camera/strobe section of the VPR were separated and remounted to the CTD rosette in order to have the camera field of view extended out $(\sim 40 \mathrm{~cm})$ from the rosette frame with an unobstructed view of the water column. Additionally the fin was positioned on the top of the rosette so that the camera view remained oriented into the flow as the CTD rosette was lowered and "towed" through the water column. This orientation minimized mats contacting and fragmenting prior to photo-documentation. Ship speed was maintained at 1 knot during CTD rosette/VPR tows in which the wire-in/out speed was maintained at $12 \mathrm{~m} \mathrm{~min}^{-1}$. Four complete round-trips (one tow-yo) of the CTD rosette/VPR package between the surface and $150 \mathrm{~m}$ were completed at each station with a calculated water volume of $0.5 \mathrm{~m}^{3}$ viewed per each $0-150 \mathrm{~m} \mathrm{leg}$ and $4.0 \mathrm{~m}^{3}$ per station tow-yo series. To provide synching of the CTD data and the VPR imagery for post-cruise analysis, a stopwatch was zeroed when the camera and strobe were turned on prior to deployment over the side. The stopwatch time was then recorded when the CTD rosette/VPR system began the first leg of the tow-yo series between the surface and $150 \mathrm{~m}$ and the time was recorded at the top and bottom of each $150 \mathrm{~m} \mathrm{leg}$.

VPR video from the tow-yo series completed at 10 stations and coincident with SCUBAsurvey and sampling of Rhizosolenia mats in the upper $20 \mathrm{~m}$ was examined post-cruise. The 
analogue imagery from these stations was digitized and sub-sampled every $0.2 \mathrm{~s}$, which assured us that we were viewing new water volume, considering the image dimensions and the ship and wire-in/out speed. The VPR data presented is from 4 of ten 2003 stations. Significant issues with the other stations' VPR image quality (i.e., focus and electronic interference problems) and/or video recorder failures rendered the VPR imagery from 6 of the 10 stations unreliable for mat quantification. IDL and ImageJ software were used to time-link CTD data to each image, to view the collected imagery and identify Rhizosolenia mats, and to compile mat counts. Mat identification was based on their distinctive morphology of intertwining diatom chains, forming aggregations approximately $\sim 1 \mathrm{~cm}$ in size (Villareal et al. 1996), a size class rarely observed or enumerated by divers. Based on the depth occurrence of each identified Rhizosolenia mat, we calculated the mat abundance within the depth intervals of 0-20 m, 20-50 m, 50-100 m and 100$150 \mathrm{~m}$.

Results and Discussion

Abundance and depth distribution of Rhizosolenia mats

Rhizosolenia mats (Fig. 1) were observed by divers at every station sampled over the 19year period spanning the cruises (Fig. 2). At low abundance $\left(<0.5 \mathrm{mat} \mathrm{m}^{-3}\right)$, patterns in the vertical distribution were difficult to detect. At high abundance $\left(>0.5\right.$ mats $\left.^{-3}\right)$, a surface

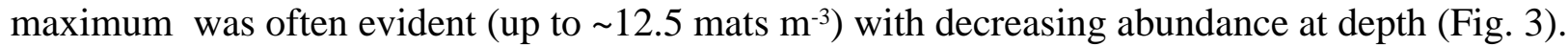
Mats were visible below depths the divers could access and were visible to the limit of vertical visibility (40-60 m). While mats were present at all stations in Fig. 2, abundance was quite variable and occasionally (4 of 96 stations) below detection limit of the sampling frame at each of the 4-6 depths measured ( 1 mat in $\left.30 \mathrm{~m}^{3}\right)$. For the 1989-2003 cruises (the 2008 cruise was snorkel only with no abundance data collected), average integrated abundance determined by divers was $4.1 \pm 5.7$ mats $\mathrm{m}^{-3}$ with a range of 0.03-27.5 mats $\mathrm{m}^{-2}$ excluding the 4 stations where mats were below enumeration limits (Fig. 4). These values were combined with literature reports from this area in Fig. 4, generating a 26-year summary of Rhizosolenia mat distribution and diver-estimated abundance.

The 2003 VPR imagery (RoMP 2003) revealed an abundance of Rhizosolenia mats that were $\leq 1 \mathrm{~cm}$ in size. These small-sized mats have previously been noted and are under-counted in diver surveys (Pilskaln et al. 2005; Villareal et al. 1999b). Our observations in RoMP2003 along a transect line from $168-177^{\circ} \mathrm{W}$ found mats were distributed to at least $150 \mathrm{~m}$ (Fig. 5). The vertical distribution had no consistent pattern with some stations (Sta. 7) showing a surface maximum, while other stations (Sta. 5) had a maximum at depth. In all cases, abundance did not decline to zero at the deepest strata $(150 \mathrm{~m})$. Integrated values (Table 1) ranged from 188-17,062 mats $\mathrm{m}^{-2}$. The station with two sets of tows approximately 10 hours apart (Sta. 12) showed good agreement between profiles with the two samples within $2 \%$ of the mean. When VPR and diver counts were compared, divers consistently under-estimated mat abundance. The $0-150 \mathrm{~m}$ integrated VPR counts were up 6-2,843 times higher than the diver-based 0-20 m integrated counts (Table 1) and a comparison of Fig 3 and 5 reveals the much higher mat densities observed in general by the VPR. VPR-based integrated abundance varied nearly 200-fold from 80-17,062 mats $\mathrm{m}^{-2}$ with $90 \%$ below diver accessible depths and had no relationship $\left(\mathrm{r}^{2}=0.08\right)$ to diver-based abundance in the $0-20 \mathrm{~m}$ range (Table 1). The 2003 counts were up to 100-fold higher than VPRbased abundance data collected 2,000 km to the east in 1996 (Villareal et al. 1999b).

\section{Nitrogen isotope values}

Rhizosolenia mats in all years were collected only in the upper mixed layer $(<10 \mathrm{~m}$ depth), a zone that routinely has only nanomolar nitrate concentrations (Brzezinski et al. 1998; Casciotti et al. 2008; Dore \& Karl 1996). The buoyancy status of the mats is closely tied to their 
$\mathrm{N}$ status. Villareal et al. (1996) noted that when compared to negatively buoyant mats (sinkers), positively buoyant mats (floaters) have significantly higher internal nitrate pools ( 1-2 vs $8+$ $\mathrm{mM}$ ), lower $\mathrm{C}: \mathrm{N}$ ratios (7-8 vs 9-11) and higher protein:carbohydrate ratios (0.4-0.6 to 1.1-1.6). These patterns are consistent with increasing nitrogen stress concurrent with the mats becoming negatively buoyant. During 2002-2003, C:N ratios in sinking mats were significantly higher than in ascending mats across the entire longitudinal gradient (Table 2), a marker resulting from unbalanced uptake of $\mathrm{N}$ and $\mathrm{C}$ and consistently tied to a vertical migration strategy (Villareal et al. 1996).

In the 2002 and 2003 samples, mat $\delta^{15} \mathrm{~N}$ was uniformly elevated across the basin (Fig. 6, 7) and averaged $2.91 \pm 0.28$ (95\% C.I., $n=181)$ when combined with historical data (Villareal et al. 1993; Villareal et al. 1999b; Villareal et al. 1996). Ascending mats were significantly (2.17 \pm 0.32 per mil versus $3.53 \pm 0.30$ per mil, $\mathrm{p}=0.05$ ) depleted in ${ }^{15} \mathrm{~N}$ relative to sinking mats (Fig. 6 , Table 2). Mats were also enriched in ${ }^{15} \mathrm{~N}$ relative to the suspended particulate material at the surface (Fig. 7). The $\delta^{15} \mathrm{~N}$ of the ambient $\mathrm{NO}_{3}{ }^{-}$pool in 2002 (RoMP2002) at 200- $400 \mathrm{~m}$ ranged from 5.29-6.73 per mil and was consistent with historical observations (Fig. 7). Inclusion of additional data from Station ALOHA(Casciotti et al. 2008) highlighted the lighter isotopic values of $\mathrm{NO}_{3}{ }^{-}$in the nutricline expected as the result of the remineralization of diazotrophically derived $\mathrm{N}$. The light $\delta^{15} \mathrm{~N}$ of mixed layer particulates is a pattern also seen at Station ALOHA and is considered typical of the oligotrophic gyres (Dore et al. 2002; Montoya et al. 2002; Montoya et al. 1992). The similarity of the Rhizosolenia mat $\delta^{15} \mathrm{~N}$ to the deep $\mathrm{NO}_{3}{ }^{-} \delta^{15} \mathrm{~N}$ is evidence that mats are generally migrating to the $150-200 \mathrm{~m}$ depth range. In the mats, the isotopic signature results from luxury nitrate uptake at high $(\mu \mathrm{M}) \mathrm{NO}_{3}$-concentrations at depth in the dark (Joseph \& Villareal 1998; Richardson et al. 1996) and assimilation from mM INP via nitrate/nitrite reductases in the low concentration $(\mathrm{nM}) \mathrm{NO}_{3}{ }^{-}$of the upper euphotic zone. Nitrate uptake does not fractionate (Comstock 2001; Robinson et al. 1998) and the internal pools initially represent the source nitrate $\delta^{15} \mathrm{~N}$.

Migrators cannot acquire sufficient $\mathrm{NO}_{3}{ }^{-}$in the mixed layer to create large INP. While rapid surge uptake at nanomolar $\mathrm{NO}_{3}{ }^{-}$concentrations has been demonstrated in the diatom Pheodactylum tricornutum (Raimbault et al. 1990), INP can only accumulate when assimilation via nitrate reductases is slower than uptake. Direct measurements of the migrating giant diatom Ethmodiscus indicate $\mathrm{NO}_{3}{ }^{-}$uptake at ambient concentrations were several orders of magnitude too low to support the observed nitrate reductase activity (Villareal et al. 1999a). Dark periods in elevated $\mathrm{NO}_{3}{ }^{-}$concentrations are required for INP to build up in Rhizosolenia spp. found in mats (Joseph \& Villareal 1998). Moreover, if these cells were building INP as a result of assimilating $\mathrm{NO}_{3}{ }^{-}$at the ambient concentrations, there should be only minimal differences between sinking and floating mats. Such uptake is inconsistent with the multiple proxies of N-limitation that are found in sinking mats and not found in floating mats (Joseph et al. 1997; Villareal et al. 1996). Due to the strictly internal $\mathrm{N}$ assimilation in the mixed layer, there is no net change of mat $\delta^{15} \mathrm{~N}$ at the surface due to reductase fractionations and/or $\mathrm{NO}_{3}{ }^{-}$uptake. However, mats in both years were actively excreting $\mathrm{NO}_{3}{ }^{-}$(Singler \& Villareal 2005). While we could not measure the isotopic composition of this excreted $\mathrm{N}$, relatively light $\mathrm{NO}_{3}{ }^{-}$would preferentially leak out and result in the observed pattern of lower mat $\delta^{15} \mathrm{~N}$ in floating (recently ascended) mats compared to sinking (depleted INP).

These data provide a picture of Rhizosolenia mat abundance across the Pacific Ocean as well as within their vertical migration range. The latitudinal distribution extends from $\sim 24^{\circ}$ to $\sim 35^{\circ} \mathrm{N}$ with additional observations near Oahu, Hawai'i (Cowen \& Holloway 1996), the coastal California current, and equatorial Pacific (Alldredge \& Silver 1982). Mats were observed over $50^{\circ}$ of longitude $(\sim 1 / 2$ the width of the Pacific Ocean) and were abundant at the western terminus 
307 of the cruise set. We found no further records in the Pacific Ocean west of this point, but the

308 broad distribution in the Indian Ocean (Carpenter et al. 1977; Wallich 1858; Wallich 1860), North

309 and South Atlantic Ocean (Caron et al. 1982; Carpenter et al. 1977; Darwin 1860), equatorial

310 Atlantic Ocean (Bauerfeind 1987) and north and south Central Pacific Ocean (Alldredge \& Silver

311 1982) supports a reasonable expectation that their distribution extends across the entire Pacific

312 Ocean (Villareal \& Carpenter 1989). Abundance is considerably lower in the Sargasso Sea

313 (Carpenter et al. 1977), although they are still present. Our 2003 VPR observations confirm the

314 earlier report that small Rhizosolenia mats dominate both numerically (Villareal et al. 1999b) and

315 in particulate Si contribution (Shipe et al. 1999) in the N. Pacific. These small mats are virtually

316 invisible to divers due to the low contrast of small mats, and the depth limitations imposed on

317 blue-water SCUBA techniques $(\sim 20 \mathrm{~m})$ preclude diver enumerations at depths (Villareal et al.

318 1999b). We conclude that the pattern of numerically dominant small mats extending to depth is

319 the prevailing distribution of Rhizosolenia mats and that the mats are both widespread and

320 abundant in the Pacific Ocean.

321

322

323

324

325

326

327

328

329

330

331

332

333

334

335

336

337

338

339

340

341

342

343

344

345

346

347

348

349

350

351

352

353

Rhizosolenia mat $\delta^{15} \mathrm{~N}$ values show a pattern dominated by values typical of sub-euphotic zone nitrate. Prior to this study, only a handful of values were published raising the possibility that these were not representative of larger scales. However, our current data set spans nearly $1 / 2$ the Pacific Ocean and clearly shows high $\delta^{15} \mathrm{~N} \mathrm{NO}_{3}{ }^{-}$pools as an $\mathrm{N}$ source. Vertical migration is a consistent feature of their biology and occurs across the entire distributional range. A reassessment of the quantitative importance of mat $\mathrm{N}$ transport is required and is particularly timely given the need to identify mechanisms capable of closing euphotic zone nitrate budgets (Ascani et al. 2013; Johnson et al. 2010). In the next section, we will consider the implications for nutrient cycling and the role of ascending motion in general in phytoplankton.

\section{Significance to oceanic nutrient cycles}

The upward nitrate flux problem derives from budgeting analysis that concludes that nitrate introduced at the base of the euphotic zone must be transported upward many $10 \mathrm{~s}$ of meters to zones of net community production and export, and that this transport occurs along a negligible concentration gradient (Ascani et al. 2013; Johnson et al. 2010). In order to assess the potential role of Rhizosolenia mats in the Pacific to this process, we calculated flux rates using our new data and previously published models. Nitrogen transport rates are calculated from abundance data coupled to turnover models. Negative buoyancy increases as the mats undergo progressive $\mathrm{N}$ limitation and sink to depth (Villareal et al. 1996). Nitrate uptake occurs at depth and in the absence of light, leading to buoyancy reversals and ascent to the surface (Richardson et al. 1996). At the surface, the pattern repeats with some fraction of the nitrate being lost via excretion (Singler \& Villareal 2005). Protist parasitism has been noted and probably results in nitrate release as well (Caron et al. 1982; Villareal \& Carpenter 1989). The overall migration cycle is shown conceptually in Fig 8 . Note that the cell growth rates of the component diatoms can be as high as $0.6 \mathrm{~d}^{-1}$ (Moore \& Villareal 1996b). Migration-based growth rates are slower due to time spent at sub-optimal light conditions while ascending/descending and during dark uptake of $\mathrm{NO}_{3}^{-}$.

Two estimates of migration-based growth rates have been published. Villareal et al. (1996) considered a simple box model that used measured mat ascent rates to calculate transit time to and from the nutricline, nitrate uptake rates based on a large diatom, and carbon-based doubling times based on oxygen evolution measurements of Rhizosolenia mats. Richardson et al (1998) used a 13 layer model over the upper 120 m derived from Kromkamp and Walsby (1990) where mat biomass is represented in carbon and nitrogen units. Photosynthesis was modeled by a standard photosynthetic model (Platt et al. 1980) modified to incorporate diel changes in 
irradiance, depth-dependent attenuation, and temperature $\mathrm{Q}_{10}$ effects. Nitrate uptake was based on Richardson et al (1996). Ascent and descent rates were based on changes in the carbon:nitrogen ratio derived from Villareal et al (1996). Loss rates are unknown, and were adjusted in the model to maintain a stable migration pattern for 5 cycles. The Villareal et al. model yielded total migration growth rates of $0.19-0.28 \mathrm{~d}^{-1}$, while the Richardson et al. model produced $0.11-0.15 \mathrm{~d}^{-1}$. While both models converge on values in 0.1-0.2 $\mathrm{d}^{-1}$ range, we have used a lower, more conservative estimate $\left(0.14 \mathrm{~d}^{-1}\right)$ for our calculations of mat turnover.

The $\mathrm{N}$ transport rates calculated from the VPR abundance ranged from 6-444 $\mu \mathrm{mol} \mathrm{N} \mathrm{m}{ }^{-2}$ $\mathrm{d}^{-1}$ (Table 1) with an average daily rate of $172 \mu \mathrm{mol} \mathrm{m}^{-2} \mathrm{~d}^{-1}$. However, our abundance data are not uniformly distributed across the year. Rhizosolenia mat observations are biased towards JuneOctober due to weather constraints on diving operations. We have only limited reports from April/May (Alldredge \& Silver 1982; Villareal \& Carpenter 1989) and no quantitative estimates for the balance of the year. Therefore, we restrict our calculation to a conservative 6 month distribution window to calculate the impact of only a six month period on the annual budget (i.e. 6 month rates $=$ the annual input via migration) based on abundance at each of our stations (range $\left.=1.1-79.9 \mathrm{mmol} \mathrm{N} \mathrm{m}^{-2} \mathrm{y}^{-1}\right)$. The upper value is directly comparable to the eddy injection $\mathrm{N}(88$ mmol $\mathrm{N} \mathrm{m}^{-2} \mathrm{y}^{-1}$ ) calculated to balance the $\mathrm{N}$ budget in the upper $250 \mathrm{~m}$ (Johnson et al. 2010). These calculations suggest that $\mathrm{N}$ transport via Rhizosolenia mats scales on an event basis that is comparable to eddy injection of nitrate to the euphotic zone, while recognizing that upward transport is not sustained at that level. This calculation is a conservative underestimate since anecdotal observations indicate mats are present year round in the eastern Pacific (Alldredge \& Silver 1982).

Finding the proper spatial and temporal scales for comparison is a challenge. Eddy injection (a physical process) and Rhizosolenia mat dynamics (a biological process) likely operate, and are certainly recorded, on different time scales. For example, the nutrient budgets were assembled for the Hawai'i Ocean Time-Series region at Station ALOHA $\left(22^{\circ} 45^{\prime} \mathrm{N}\right)$, a latitude that has high trade winds much of the year that inhibit diving operations. Rhizosolenia mat data were collected several hundred kilometers to the north $\left(\sim 28-30^{\circ}\right)$ where wind conditions permit divers to routinely enter the water. Eddy turbulent kinetic energy and numbers of eddies in the mat collection areas are low (Chelton et al. 2011) relative to Station ALHOA. We have no site where both long-term $\mathrm{N}$ budgets and Rhizosolenia mat abundance are available. In addition, Rhizosolenia mats are not unique in their migration strategy, and comprehensive consideration of phytoplankton upward nitrate transport requires inclusion of other migrating phytoplankton taxa. A brief review is presented here to provide the required perspective and background to justify inclusion of these taxa in the subsequent calculations.

\section{Other vertically migrating phytoplankton taxa: life history and abundance}

The literature on other migrating, non-flagellated phytoplankton in the open sea is dispersed and the natural history of this group poorly represented in the literature of the past several decades. There are several taxa that must be represented and spanning a broad taxonomic range: Pyrocystis, Halosphaera, Ethmodiscus, and free living Rhizosolenia.

Pyrocystis species are positively buoyant warm water, non-motile dinoflagellates with a dominant cyst-like non-motile stage typically $10^{7} \mu \mathrm{m}^{3}$ (Rivkin et al. 1984). They undergo a migration to the nutricline (Rivkin et al. 1984) and have been considered members of the shade flora (Sournia 1982). Reproduction occurs by release of a brief reproductive stage from a cystlike vegetative form (Swift \& Durbin 1971). Bilobate reproductive stages release immature vegetative stages that swell up to near full size in $\sim 10$ min (Swift \& Durbin 1971), become positively buoyant within $13 \mathrm{~h}$ and indistinguishable from the cyst-like form after $15 \mathrm{~h}$ (Swift et al. 1976b). Thecate, dinoflagellate stages appear as swarmers in some species (Meunier \& Swift 
402

403

404

405

406

407

408

409

410

411

412

413

414

415

416

417

418

419

420

421

422

423

424

425

426

427

428

429

430

431

432

433

434

435

436

437

438

439

440

441

442

443

444

445

446

447

448

449

1977; Swift \& Durbin 1971). Buoyancy reversals in the cyst form occur when negativelybuoyant nutrient-depleted stages descending to the nutricline are resupplied with $\mathrm{NO}_{3}{ }_{3}^{-}$and become positively buoyant, consistent with acquiring $\mathrm{NO}_{3}{ }^{-}$at depth (Ballek \& Swift 1986). Nonmotile stage cells take up $\mathrm{NO}_{3}{ }^{-}$and $\mathrm{NH}_{4}{ }^{+}$at almost equal rates in the light and dark (Bhovichitra \& Swift 1977) and field-collected cells at the surface contain up to $8 \mathrm{mM}$ INP (Villareal \& Lipschultz 1995). Growth rates in culture range up to 0.2 div day $^{-1}$ (Bhovichitra \& Swift 1977), with doubling times of 4-14 (P. fusiformis) and 10-22 days (P. noctiluca) in field populations (Swift et al. 1976a). Abundance is reported up to 200 cells $^{-3}$ in the Atlantic Ocean (Rivkin et al. 1984; Swift et al. 1976a) and 40-50 cells $\mathrm{m}^{-3}$ in the Pacific Ocean (Sukhanova 1973; Sukhanova \& Rudyakov 1973). Photosynthetic and light acclimation curves from field populations showed a time-averaging of the light field such that $\mathrm{C}$ fixation at the surface supported a near-constant doubling rate throughout the euphotic zone (Rivkin et al. 1984).

Halosphaera is a genus of positively buoyant non-motile phycomate prasinophytes noted throughout the oceans (poles to tropics) from the earliest days of oceanography (Agassiz 1906; Schmitz 1878; Sverdrup et al. 1942). It is listed as a member of the shade flora (Sournia 1982). Reproduction occurs by swarmer formation with up to 50,000 flagellated swarmers released from a phycoma (Parke \& den Hartog-Adams 1965). Individual swarmers can vegetatively reproduce, and then after 14-21 days start to increase in size at 5-10 $\mu \mathrm{m} \mathrm{d}^{-1}$ to reach a species-specific diameter of several hundred microns. At this time, the cytoplasm undergoes numerous divisions to form flagellated swarmers (Parke \& den Hartog-Adams 1965). Size and photosynthetic rates (3- 6 ng C cell' ${ }^{-1} \mathrm{~h}^{-1}$ ) are similar to Pyrocystis (Rivkin \& Lessard 1986). Growth rates are poorly known; reproduction is linked to lunar rhythms in the North Sea and adjacent waters. INP up to $100 \mathrm{mM}$ have been documented (Villareal \& Lipschultz 1995), and deep populations with seasonal descent and ascent are noted in the Mediterranean Sea (Wiebe et al. 1974). Abundance ranges from $\sim 10^{-3}$ cells m$^{-3}$ (Wiebe et al. 1974) to 340 cells L $^{-1}$ (Gran 1933). Halosphaera is representative of a number of species that reproduce by phycoma and swarmer formation, including members of the genus Pterosperma. Typical concentrations reported for the Mediterranean are 1-3 L ${ }^{-1}$; Pterosperma is reported at $\sim 40$ cells L ${ }^{-1}$ in HNLC areas of the Pacific Ocean (Gomez et al. 2007). In the text calculation on N-transport, we have assumed an abundance of 200 cells m$~^{-3}\left(0.2\right.$ cells $\left.\mathrm{L}^{-1}\right)$ as a conservative mid range value of the 9 order of magnitude abundance range for this group.

Ethmodiscus spp. are solitary centric diatoms and are the largest diatoms known with a diameter of $>2,000 \mu \mathrm{m}$ in the Pacific Ocean; cells are somewhat smaller in the Atlantic Ocean (Swift 1973; Villareal \& Carpenter 1994; Villareal et al. 1999a). Internal nitrate concentrations from surface-collected samples reached $27 \mathrm{mM}$ in the Sargasso Sea (Villareal \& Carpenter 1994). Cells become increasing negatively buoyant as INP are depleted with positively buoyant cells having significantly higher internal nitrate concentrations than sinking cells (Villareal \& Lipschultz 1995). Nitrate reductase activity, $\mathrm{C}$ doubling and Si uptake rates can support doubling times of 45-75 h in large Pacific cells (Villareal et al. 1999a); cell cycle analysis suggests division rates of 0.24-0.42 div d ${ }^{-1}$ in smaller Atlantic cells (Lin \& Carpenter 1995). Pooled cells had $\delta^{15} \mathrm{~N}$ values of 2.56-5.09 per mil (Villareal et al. 1999a). Maximum reported abundance is 27.3 cells m$^{-}$ ${ }^{3}$ in equatorial waters off Chile (Belyayeva 1972), but abundance generally ranges from 0.03-4.7 cells $\mathrm{m}^{-3}$ in the Atlantic and 0.02-6 cells $\mathrm{m}^{-3}$ in the central Pacific gyre (Belyayeva 1968; Belyayeva 1970; Villareal et al. 2007). In the Pacific, abundance increases westward into the open Pacific Ocean with the highest values near the equator (Belyayeva 1970). Ascent rates reach $4.9 \mathrm{~m} \mathrm{hr}^{-1}$ (Moore \& Villareal 1996c) and like Pyrocystis and Rhizosolenia, appears to result from active ionic regulation of inorganic (Woods \& Villareal 2008) and organic compounds required for osmoregulation (Boyd \& Gradmann 2002). Living cells have been collected in 
450

451

452

453

454

455

456

457

458

459

460

461

462

463

464

465

466

467

468

469

470

471

472

473

474

475

476

477

478

479

480

481

482

483

484

485

486

487

488

489

490

491

492

493

494

495

496

497

downward facing sediment traps at $5400 \mathrm{~m}$ (Villareal 1993) indicating living cells with positive buoyancy at great depth.

Several of the Rhizosolenia species that are found in mats also exist as free-living diatom chains. These species exhibit similar characteristics to mat-forming spp. INP are present at up to $26 \mathrm{mM}$ (Moore \& Villareal 1996b). Individual species (non-aggregated) ascend at up to $6.9 \mathrm{~m} \mathrm{~h}^{-1}$, depending on species and are also listed as members of the shade flora (Sournia 1982). Growth rates for buoyant species range from $0.37-0.78 \mathrm{div} \mathrm{d}^{-1}$ in the laboratory and up to $1.0 \mathrm{div} \mathrm{d}^{-1}$ in the field (Moore \& Villareal 1996b; Yoder et al. 1994). Other characteristics are similar to Rhizosolenia mats (Moore \& Villareal 1996b). Little abundance information is available. $R$. castracanei is reported at up to $10^{3}$ cells $\mathrm{L}^{-1}$ from the Bay of Naples (Marino \& Modigh 1981) and 50 cells $\mathrm{m}^{-3}$ in Sargasso Sea warm core rings (T.A.Villareal and T. J. Smayda, unpublished data). R. debyana reached $10^{6}$ cells $\mathrm{L}^{-1}$ in the Gulf of California in bloom conditions (GarateLizarraga et al. 2003); similar abundance was likely in the equatorial Pacific "Line in the Sea" front accumulation (Yoder et al. 1994).

\section{Significance of migrating phytoplankton to the North Pacific $N$ budget}

In this final step of the calculation, we incorporated these additional migrating taxa into the model. In order to compare the spatially limited input of a mesoscale eddy with the broader distribution patterns of phytoplankton, we combined conservative abundance data and growth rate estimates for Halosphaera, Ethmodiscus, Pyrocystis and solitary Rhizosolenia spp. (Table 1) and calculated their combined contributions to $\mathrm{NO}_{3}{ }^{-}$flux to be $62.5 \mu \mathrm{mol} \mathrm{N} \mathrm{m} \mathrm{m}^{-2}$. These estimates are very generalized and can only be used to scale the fluxes. Using profiler-derived estimates of eddy $\mathrm{NO}_{3}{ }^{-}$injection from the Pacific Ocean (Johnson et al. 2010), we considered the nitrate input via eddy injection over the entire time frame of measurement $\left(145 \mathrm{mmol} \mathrm{NO}_{3}{ }^{-2} \mathrm{~m}^{-2}\right.$ over 600 days), and computed an average daily eddy injection rate of $242 \mu \mathrm{mol} \mathrm{NO}_{3}^{-} \mathrm{m}^{-2} \mathrm{~d}^{-1}$. Nitrate transport of Rhizosolenia mats $\left(2002 / 2003\right.$ data; $\left.172 \mu \mathrm{mol} \mathrm{NO}_{3}^{-} \mathrm{m}^{-2} \mathrm{~d}^{-1}\right)$ combined with other taxa (values from Table 1) equals $235 \mu \mathrm{mol} \mathrm{N} \mathrm{m} \mathrm{m}^{-2} \mathrm{~d}^{-1}$. This nearly equals the average daily eddy injection of nitrate $\left(242 \mu \mathrm{mol} \mathrm{NO}_{3}{ }^{-} \mathrm{m}^{-2} \mathrm{~d}^{-1}\right)$. Our previous VPR estimates of mats (Villareal et al. 1999b) is lower, and reduces the upward transport to $179 \mu \mathrm{mol} \mathrm{N} \mathrm{m} \mathrm{N}^{-2}$ if we include those abundance estimates. However, within the uncertainties of both calculations, this is remarkably good agreement. On a time scale of weeks to months, migrating phytoplankton can transport sufficient $\mathrm{N}$ from deep euphotic zone pools to the upper euphotic zone to significantly impact nutrient budgets. Upward biological transport of nitrate is quantitatively important to the biogeochemistry of surface waters in the N. Pacific gyre. Other mechanisms may exist, but migration alone appears to be sufficient to dominate the required upward transport.

The abundance range found in the vertically migrating flora is not trivial; Halosphaera abundance records span 9 orders of magnitude and the abundance used profoundly affects the calculations. While Halosphaera may be extreme, it highlights the difficulties in enumerating a frequently rare and largely ignored component of the marine phytoplankton. Moreover, there are significant gaps in our knowledge of the biology of these taxa, their life cycles and migration timing that create uncertainties in how to apply this information.

Acquisition of imported $\mathrm{N}$ by other phytoplankton requires release of internal nitrate pools or remineralization by grazers. Rhizosolenia mats directly release $\mathrm{NO}_{3}{ }^{-}$. Using excretion rates (Singler \& Villareal 2005) for $\mathrm{NO}_{3}^{-}$(2 cruise range: $22.8-23.7 \mathrm{nmol} \mathrm{N} \mu \mathrm{g} \mathrm{chl}{ }^{-1} \mathrm{~h}^{-1}$ ) and published N:Chl ratios (1.7 $\mu \mathrm{mol} \mathrm{N}: \mu \mathrm{g}$ chl a) (Villareal et al. 1996), we calculate N-specific release of $\sim 1.3 \% \mathrm{~h}^{-1}$ or up to $31 \% \mathrm{~d}^{-1}$. Release rates vary with Fe status, buoyancy status and location along the E-W gradient (Singler \& Villareal 2005); however, it is clear that over time scales of days to weeks, Rhizosolenia mats (and by inference, other high nitrate cells) will release $\mathrm{NO}_{3}{ }^{-}$. Grazers on this size class are poorly known. Hyperiid amphipods are associated with 
mats, as well as parasitic dinoflagellates and ciliates (Caron et al. 1982; Villareal \& Carpenter 1989; Villareal et al. 1996). Nitrate is probably released during feeding by myctophids as well (Robison 1984). Such release by both Rhizosolenia and other ascending, high $\mathrm{NO}_{3}{ }^{-}$cells provides the needed mechanism for transporting $\mathrm{NO}_{3}{ }^{-}$to the required depths for net community production (Johnson et al. 2010), balancing isotope budgets (Altabet 1989), and providing sources for the observed difference in the $\delta^{15} \mathrm{~N}_{\text {of }} \mathrm{NO}_{3}{ }^{-}$in small pro- and eukaryotes (Fawcett et al. 2011). Energy dissipation via reduction of oxidized $\mathrm{N}$ and subsequent release also provides additional pathways to the environment from nitrate-using cells (Lomas et al. 2000) although the isotope systematics of the various products would need to be carefully considered for their contribution to the resultant particulate signal. However, this $\mathrm{N}$ would contribute to meeting $\mathrm{N}$ budget requirements.

Using flow-cytometer sorted populations coupled with mass spectrometry, Fawcett et al (2011) noted uniformly low $\delta^{15} \mathrm{~N}$ values in prokaryotic phytoplankton from the Sargasso Sea while small $(<30 \mu \mathrm{m})$ eukaryotes showed a higher mean value with significant variability suggestive of nitrate utilization from beneath the euphotic zone. Our results suggest that some of this nitrate may be made available by migrating phytoplankton. However, this requires differential availability of nitrate to the small pro- and eukaryote populations. In general, picoplankton can respond to low $(<100 \mathrm{nM})$ nitrate additions (Glover et al. 2007). However, the response of specific taxa in this size class may not be uniform. Synechococcus, in most cases, appears to be able to utilize both $\mathrm{NO}_{3}{ }^{-}$and $\mathrm{NH}_{4}{ }^{+}$while Prochlorococcus initially appeared unable to utilize either form of $\mathrm{N}$ (Moore et al. 2002), although recent work has noted evidence growth on $\mathrm{NO}_{3}{ }^{-}$(Casey et al. 2007). The general patterns suggest $\mathrm{NH}_{4}{ }^{+}$utilization supports Procholorococcus while Synechococcus appears to have retained the capacity to utilize both $\mathrm{NO}_{3}{ }^{-}$ and $\mathrm{NO}_{2}{ }^{-}$in the presence of $\mathrm{NH}_{4}^{+}$(Bird \& Wyman 2003; Wyman \& Bird 2007). Exceptions exist in both groups (Fuller et al. 2003) and considerable genomic diversity in $\mathrm{N}$ uptake exists in the two groups (Scanlan et al. 2009). Temporal changes in populations can be expected as they adapt to seasonal patterns of nutrient availability in the water column (Bragg et al. 2010). While this example focuses on prokaryotes due to the greater body of work available on oceanic forms, the relevant point is that $\mathrm{NO}_{3}{ }^{-}$injections above the nutricline can reasonably be expected to be differentially assimilated by subpopulations within the phytoplankton, and that, at times, significant components of the prokaryotic phytoplankton may not have access to $\mathrm{NO}_{3}{ }^{-}$.

\section{Conclusions}

Upward transport by phytoplankton is a quantitatively significant mechanism for transporting nutrients to the oceanic euphotic zone across broad regions of the oligotrophic open sea. Our calculations indicate that this biological flux in the Pacific can dominate the $\mathrm{NO}_{3}{ }^{-}$ transport into the upper euphotic zone that budgets require to support the observed DIC drawdown in the summer time. There are multiple taxa involved and all oligotrophic seas possess several of them. In these large cells, $\mathrm{NO}_{3}{ }^{-}$excretion is probably the inevitable consequence of the $\mathrm{mM}$ to $\mathrm{nM}$ concentration gradients across the cell surface (Ter Steege et al. 1999). Although the congruence between the required $\mathrm{N}$ flux for budgets and the contribution from migrating flora is surprisingly good, the deeper significance of our finding is in the combined role that biology and physics play in moving essential nutrients in both directions between deep pools and the surface.

$\mathrm{NO}_{3}{ }^{-}$importation by the vertically migrating flora is but one component of active material rearrangement by the biota. Zooplankton diel vertical migration transports material out of the euphotic zone for remineralization and is a significant loss to the euphotic zone (Steinberg et al. 2000; Steinberg et al. 2002; Steinberg et al. 2008). It can represent 10-50\% of the C and N flux 
546

547

548

549

550

551

552

553

554

555

556

557

558

559

560

561

562

563

564

565

566

567

568

569

570

571

572

573

574

575

576

577

578

579

580

581

582

583

584

585

586

587

588

589

590 out of the euphotic zone (Bollens et al. 2011) and up to 82\% of the P flux (Hannides et al. 2009). When combined with phytoplankton vertical migration, the picture that emerges is of biological transport, both upward and downward, superimposed on both physically driven and biologically mediated new $\mathrm{N}$ inputs. Nitrogen-fixation coupled with $\mathrm{NO}_{3}{ }^{-}$release by the vertically migrating flora creates a zone of biological nutrient sources near the surface distinct from a deeper zone dominated by physical processes. In the Pacific Ocean, surface and deep phytoplankton communities persist over 1000's of km with a separation at the $\sim 100 \mathrm{~m}$ transition from nutrientto light-limitation (Venrick 1982; Venrick 1999). A pattern emerges of a hydrographically structured two (or more)-layered euphotic zone with differing phytoplankton communities and biological/physical inputs of new N (Banse 1987; Coale \& Bruland 1987; Herbland 1983). Turbulent diffusion and eddy injection of $\mathrm{NO}_{3}{ }^{-}$dominates at the base of the euphotic zone; biological processes move $\mathrm{N}$ towards the surface and together with $\mathrm{N}_{2}$-fixation provide the community production required to close new N nutrient budgets. Atmospheric inputs may dominate truly external inputs to the surface zone (Donaghay et al. 1991).

Ascending behavior in non-flagellated phytoplankton is not limited to giant cells in the ocean. Positive buoyancy is the result of lift (cell sap density) exceeding ballast (silicate frustule in diatoms, cell wall in others)(Woods \& Villareal 2008) and theoretical considerations have suggested that there is a minimal cell size that can support positive buoyancy (Villareal 1988). However, there is persistent evidence of positive buoyancy in smaller (10s vs 100s $\mu \mathrm{m}$ diameter) spring bloom diatoms (Acuña et al. 2010; Jenkinson 1986; Lännergren 1979), Antarctic diatoms (Hardy 1935), deep chlorophyll maximum diatoms (Waite \& Nodder 2001) and post-auxospore diatoms (Smayda \& Boleyn 1966; Waite \& Harrison 1992). Cells as small as $200 \mu \mathrm{m}^{3}$ (equivalent spherical diameter $=\sim 8 \mu \mathrm{m}$ ) could be capable of positive buoyancy (Waite et al. 1997). These observations are scattered, but consistent with laboratory data that in sinking rate experiments, some fraction of healthy cultures are generally positively buoyant (Bienfang 1981). Stoke's velocities of this size range of phytoplankton are $<1-2 \mathrm{~m} \mathrm{~d}^{-1}$ (Smayda 1970); however, aggregation and chain formation could increase the effective size and the Stoke's velocity. There are numerous aspects of this phenomenon that are unresolved, but the core observation that ascending behavior occurs in a variety of non-flagellated phytoplankton cannot be ignored.

The data that document ascending behavior in a diversity of both small and large cells are contrary to standard concepts of passive phytoplankton settling in the ocean, but are consistent with evolutionary adaptation to a physical partitioning of light and nutrient resources (Ganf \& Oliver 1982; Smetacek 1985). We have considered only the largest vertical migrators, but persistent reports of small, ascending phytoplankton coupled with the long-noted potential of flagellated forms to vertically migrate in the open sea (Nielsen 1939) opens entirely new linkages between events in the deep euphotic zone (Brown et al. 2008; McGillicuddy et al. 2007) and the response of surface communities. The ascent of some fraction of the biomass is a mechanism rarely considered in models of nutrient cycling in the open sea but should not be ignored. Quantifying these upward fluxes is a challenge for existing instrumentation and will likely require new approaches.

Acknowledgements

We are deeply grateful for the able assistance of numerous officers and crews of the UNOLS research vessels that supported these operations over the years. This paper is dedicated to Professor Theodore J. Smayda in celebration of his 60 years of contributions to phytoplankton ecology. 
Fig. 1. Rhizosolenia mats. All scale bars are approximate. A. Orientation view of Rhizosolenia mats in-situ. Numerous mats are evident. Station 13, 5 July 2002, $30.44^{\circ} \mathrm{N} 145.45^{\circ} \mathrm{W}$ B. Individual Rhizosolenia mat. Station 13,5 July $2002,30.43^{\circ} \mathrm{N} 145.45^{\circ} \mathrm{W}$ C. micrograph of individual mat Rhizosolenia chains. Brown regions are the nuclear mass and protoplasm of individual chains. Some cell lysis is evident due to the pressure of the cover slip. Sta. 13, 7 Sept. $199231.38^{\circ} \mathrm{N} 149.89^{\circ} \mathrm{W}$.

Fig. 2. Cruise track map of sampling locations. Cruises RNBT17WT (Mar/April 1989), W9208C (Aug. 1992), PacMat (May/June. 1993), RoMP95 (Jun./Aug. 1995), RoMP96 (Jun./Aug. 1996), RoMP2002 (Jun. 2002), RoMP2003 (Aug./Sept. 2003), POOB2008 (Jul. 2008). Data has partially or completely presented in: RNBT17WT (Villareal \& Carpenter 1989), W9208C \& PacMat (Villareal et al. 1993; Villareal et al. 1996), RoMP95 \& RoMP96 (Pilskaln et al. 2005; Shipe et al. 1999; Villareal et al. 1999b), RoMP2002, RoMP2003 \& POOB2008 (this report).

Fig. 3. Vertical distribution and abundance of Rhizosolenia mats observed by divers. Abundance was estimated visually using a metered frame (Villareal et al. 1996). The 1982 data are from Alldredge and Silver (1982). The remaining data (67 stations) are from cruises summarized in Fig. 2. For purposes of plotting, a zero abundance at a depth was recorded as $0.01 \mathrm{mats} \mathrm{m}^{-3}$. Integrated mat abundance used actual values collected. No abundance data were available from POOB2008.

Fig. 4. Rhizosolenia mat integrated abundance. Diver-collected abundance in the upper $60 \mathrm{~m}$. Data are from 7 cruises spanning 1989-2003 and literature sources (Alldredge \& Silver 1982; Martinez et al. 1983). Total number of stations, $n=96$. Filled squares ( 1 ) indicate stations where mats were observed but not quantified. The A is Sta. ALOHA of the Hawai'i Ocean TimeSeries (HOT).

Fig. 5. Vertical distribution of Rhizosolenia mats observed by the video plankton recorder. Data are from Aug./Sept. 2003 (RoMP2003). Station positions are given in the figure. Data is for all sizes of mats observed by the VPR.

Fig. 6. Histogram of Rhizosolenia mat $\delta^{15}$ N. $(n=170)$. Bins are 2 per mil with the lower value included in the bin and the higher value representing the upper limit. Ascending mats were statistically lighter $(2.17 \pm 0.32$ per mil, $\mathrm{n}=125)$ than descending mats $(3.53 \pm 0.39$ per mil, $\mathrm{n}=45)$. Error bars are $95 \%$ confidence intervals. Samples were collected at regular intervals on RoMP2002 and RoMP2003 (Fig. 2)

Fig. 7. Particulate $\delta^{15} \mathrm{~N}$ and nitrate $\delta^{15} \mathrm{~N}$ of the sampled areas in the Pacific Ocean. Suspended particulate data (open symbols) are from the RoMP2002 cruise, pooled from Stas. $1\left(22.197{ }^{\circ} \mathrm{N}\right.$ $\left.157.960^{\circ} \mathrm{W}\right), 5\left(28.008^{\circ} \mathrm{N} 158.019^{\circ} \mathrm{W}\right), 7\left(28.000^{\circ} \mathrm{N} 153.736^{\circ} \mathrm{W}\right)$ and $10\left(30.504{ }^{\circ} \mathrm{N} 149.615\right.$ $\left.{ }^{\circ} \mathrm{W}\right)$. Rhizosolenia mat $\delta^{15} \mathrm{~N}$ is averaged (box and whiskers) over all cruises ( $\pm 95 \%$ C.I.). Open symbols are suspended particulate material $\delta^{15} \mathrm{~N}$, large solid symbols are dissolved $\mathrm{NO}_{3}{ }^{-} \delta^{15} \mathrm{~N}$, small filled squares are the dissolved $\mathrm{NO}_{3}$ - concentration (RoMP2003 stations). Red " $\mathrm{X}$ " are from Casciotti et al. (2008) at Station ALOHA. Black "X" are from the 2002 stations. 
632 Fig. 8. Conceptual model of vertical migration in Rhizosolenia mats and other giant

633 phytoplankton. In this simplified representation, depth intervals are given in only general terms to 634 allow for significant life history variations in the various taxa noted in the text.. Data soures: rate 635 measurements supporting time at depth (Richardson et al. 1996), surface photosynthetic rates 636 (Villareal et al. 1996), $\mathrm{NO}_{3}{ }^{-}$assimilation (Joseph et al. 1997), ascent rates (Moore \& Villareal 637 1996a; Moore \& Villareal 1996c). 


\section{References}

Acuña JL, Lopez-Alvarez M, Nogueira E, and Gonzalez-Taboada F. 2010. Diatom flotation at the onset of the spring phytoplankton bloom: an in situ experiment. Marine Ecology-Progress Series 400:115-125.

Agassiz A. 1906. Reports on the scientific results of the expedition to the Eastern Tropical Pacific, in charge of Alexander Agassiz, by the U.S. Fish Commission steamer "Albatross," from October, 1904, to March, 1905, Lieut. Commander L. M. Garrett, U.S.N., Commanding. V. General Report of the Expedition. Memoirs of the Museum of Comparative Zoology at Harvard College, 33:1-77.

Alldredge AL, and Cox JL. 1982. Primary production and chemical composition of marine snow in surface waters of the Southern California Bight. Journal of Marine Research 40:517527.

Alldredge AL, and Silver MW. 1982. Abundance and production rates of floating diatom mats (Rhizosolenia castracanei and Rhizosolenia imbricata var. shrubsolei) in the eastern Pacific Ocean. Marine Biology (Berlin) 66:83-88.

Altabet MA. 1989. A time-series study of the vertical structure of nitrogen and particle dynamics in the Sargasso Sea. Limnology and Oceanography 34:1185-1201.

Ascani F, Richards KJ, Firing E, Grant S, Johnson KS, Jia Y, Lukas R, and Karl DM. 2013. Physical and biological controls of nitrate concentrations in the upper subtropical North Pacific Ocean. Deep Sea Research Part II-Topical Studies in Oceanography 93:119-134.

Azam F, Fenchel T, Field JG, Gray JS, Meyerreil LA, and Thingstad F. 1983. The ecological role of water-column microbes in the sea. Marine Ecology-Progress Series 10:257-263.

Ballek RW, and Swift E. 1986. Nutrient- and light-mediated buoyancy control of the oceanic nonmotile dinoflagellate Pyrocystis noctiluca Murray ex Haeckel. Journal of Experimental Marine Biology and Ecology 101:175-192.

Banse K. 1987. Clouds, deep chlorophyll maxima and the nutrient supply to the mixed layer of stratified water bodies. Journal of Plankton Research 9:1031-1036.

Bauerfeind E. 1987. Primary production and phytoplankton biomass in the equatorial region of the Atlantic at $22^{\circ}$ west. Oceanologica Acta Proceedings of the International Symposium on Equatorial Vertical Motion:131-136.

Beardall J, Allen D, Bragg J, Finkel ZV, Flynn KJ, Quigg A, Rees TAV, Richardson A, and Raven JA. 2009. Allometry and stoichiometry of unicellular, colonial and multicellular phytoplankton. New Phytologist 181:295-309.

Belyayeva TV. 1968. Range and numbers of diatoms in the genus Ethmodiscus Castr. in the Pacific plankton and sediments. Oceanology, Academy of Science, USSR 8:79-85, (Translation by the American Geophysical Union).

Belyayeva TV. 1970. Abundance of Ethmodiscus in Pacific plankton. Oceanology, Academy of Science, USSR 10:672-675 (Translation by the American Geophysical Union).

Belyayeva TV. 1972. Distribution of large diatoms in the southeastern Pacific. Oceanology 12:400-407 (English translation).

Bhovichitra M, and Swift E. 1977. Light and dark uptake of nitrate and ammonium by large oceanic dinoflagellates: Pyrocystis noctiluca, Pyrocystis fusiformis and Dissodinium lunula. Limnology and Oceanography 22:73-83.

Bienfang PK. 1981. SETCOL - A technologically simple and reliable method of measuring phytoplankton sinking rates. Candian Journal of Fisheries and Aquatic Sciences 38:12891294. 
Bird C, and Wyman M. 2003. Nitrate/nitrite assimilation system of the marine picoplanktonic cyanobacterium Synechococcus sp. strain WH 8103: effect of nitrogen source and availability on gene expression. Applied and Environmental Microbiology 69:7009-7018.

Bollens SM, Rollwagen-Bollens G, Quenette JA, and Bochdansky AB. 2011. Cascading migrations and implications for vertical fluxes in pelagic ecosystems. Journal of Plankton Research 33:349-355.

Boyd CM, and Gradmann D. 2002. Impact of osmolytes on buoyancy of marine phytoplankton. Marine Biology 141:605-618.

Boyd PW, Jickells T, Law CS, Blain S, Boyle EA, Buesseler KO, Coale KH, Cullen JJ, de Baar HJW, Follows M et al. . 2007. Mesoscale iron enrichment experiments 1993-2005: Synthesis and future directions. Science (Washington, DC) 315:612-617.

Bragg JG, Dutkiewicz S, Jahn O, Follows MJ, and Chisholm SW. 2010. Modeling Selective Pressures on Phytoplankton in the Global Ocean. PLoS ONE 5.

Brown SL, Landry MR, Selph KE, Yang EJ, Rii YM, and Bidgare RR. 2008. Diatoms in the desert: Plankton community response to a mesoscale eddy in the subtropical North Pacific. Deep-Sea Research Part Ii-Topical Studies in Oceanography 55:1133-1138.

Brzezinski MA, Villareal TA, and Lipschultz F. 1998. Silica production and the contribution of diatoms to new and primary production in the central North Pacific. Marine Ecology Progress Series 167:89-101.

Burkholder JM, Glibert PM, and Skelton HM. 2008. Mixotrophy, a major mode of nutrition for harmful algal species in eutrophic waters. Harmful Algae 8:77-93.

Caron DA, Davis PG, Madin LP, and Sieburth JM. 1982. Heterotrophic bacteria and bactivorous protozoa in oceanic macroaggregates. Science (Washington, DC) 218:795-797.

Carpenter EJ, Harbison RG, Madin LP, Swanberg NR, Biggs DC, Hulburt EM, McAlister VL, and McCarthy JJ. 1977. Rhizosolenia Mats. Limnology and Oceanography 22:739-741.

Casciotti KL, Trull TW, Glover DM, and Davies D. 2008. Constraints on nitrogen cycling at the subtropical North Pacific Station ALOHA from isotopic measurements of nitrate and particulate nitrogen. Deep-Sea Research Part Ii-Topical Studies in Oceanography 55:1661-1672.

Casey JR, Lomas MW, Mandecki J, and Walker DE. 2007. Prochlorococcus contributes to new production in the Sargasso Sea deep chlorophyll maximum. Geophysical Research Letters 34.

Chelton DB, Schlax MG, and Samelson RM. 2011. Global observations of nonlinear mesoscale eddies. Progress in Oceanography 91:167-216.

Clark DR, Rees AP, and Joint I. 2008. Ammonium regeneration and nitrification rates in the oligotrophic Atlantic Ocean: Implications for new production estimates. Limnology and Oceanography 53:52-62.

Coale KH, and Bruland KW. 1987. Oceanic stratified euphotic zone as elucidated by 234Th:238U disequilibria. Limnology and Oceanography 32:189-200.

Comstock JP. 2001. Steady-state isotopic fractionation in branched pathways using plant uptake of NO3- as an example. Planta 214:220-234.

Cowen JP, and Holloway CF. 1996. Structural and chemical analysis of marine aggregates: insitu macrophotography and laser confocal and electron microscopy. Marine Biology (Berlin) 126:163-174.

Darwin C. 1860. The Voyage of the Beagle. New York: Doubleday.

de Baar HJW, Boyd PW, Coale KH, Landry MR, Tsuda A, Assmy P, Bakker DCE, Bozec Y, Barber RT, Brzezinski MA et al. . 2005. Synthesis of iron fertilization experiments: From the iron age in the age of enlightenment. Journal of Geophysical Research-Oceans 110. 
DeVries T, Primeau F, and Deutsch C. 2012. The sequestration efficiency of the biological pump. Geophysical Research Letters 39.

Donaghay PL, Liss PS, Duce RA, Kester DR, Hanson AK, Villareal TA, Tindale N, and Gifford DJ. 1991. The role of episodic atmospheric nutrient inputs in the chemical and biological dynamics of oceanic ecosystems. Oceanography Magazine 4:62-70.

Dore JE, Brum JR, Tupas LM, and Karl DM. 2002. Seasonal and interannual variability in sources of nitrogen supporting export in the oligotrophic subtropical North Pacific Ocean. Limnology and Oceanography 47:1595-1607.

Dore JE, and Karl DM. 1996. Nitrification in the euphotic zone as a source for nitrite, nitrate, and nitrous oxide at Station ALOHA. Limnology and Oceanography 41:1619-1628.

Dugdale RC, and Goering JJ. 1967. Uptake of new and regenerated forms of nitrogen in primary productivity. Limnology and Oceanography 12:196-206.

Emerson S, and Hayward TL. 1995. Chemical tracers of biological processes in shallow waters of North Pacific: preformed nitrate distributions. Journal of Marine Research 53:499-513.

Eppley RW, and Peterson BJ. 1979. Particulate organic matter flux and planktonic new production in the deep ocean. Nature (London) 282:677-680.

Fawcett SE, Lomas M, Casey JR, Ward BB, and Sigman DM. 2011. Assimilation of upwelled nitrate by small eukaryotes in the Sargasso Sea. Nature Geoscience 4:717-722.

Fawcett SE, and Ward BB. 2011. Phytoplankton succession and nitrogen utilization during the development of an upwelling bloom. Marine Ecology-Progress Series 428:13-31.

Fuller NJ, Marie D, Partensky F, Vaulot D, Post AF, and Scanlan DJ. 2003. Clade-specific 16S ribosomal DNA oligonucleotides reveal the predominance of a single marine Synechococcus clade throughout a stratified water column in the Red Sea. Applied and Environmental Microbiology 69:2430-2443.

Ganf GG, and Oliver RL. 1982. Vertical separation of light and available nutrients as a factor causing replacement of green algae by blue-green algae in the plankton of a stratified lake. Journal of Ecology 70:829-844.

Garate-Lizarraga I, Siqueiros-Beltrones DA, and Maldonado-Lopez V. 2003. First record of a Rhizosolenia debyana bloom in the Gulf of California, Mexico. Pacific Science 57:141145.

Glover HE, Garside C, and Trees CC. 2007. Physiological responses of Sargasso Sea picoplankton to nanomolar nitrate perturbations. Journal of Plankton Research 29:263274.

Goldman JC. 1988. Spatial and temporal discontinuities of biological processes in pelagic surface waters. In: Rothschild BJ, ed. Toward a Theory on Biological-Physical interactions in the World Ocean. Netherlands: Kluwer Academic Publishers, 273-296.

Gomez F, Claustre H, Raimbault P, and Souissi S. 2007. Two High-Nutrient Low-Chlorophyll phytoplankton assemblages: The tropical central Pacific and the offshore Peru-Chile Current. Biogeosciences 4:1101-1113.

Gran HH. 1933. Studies on the biology and chemistry of the Gulf of Maine. II. Distribution of phytoplankton in August, 1932. Biological Bulletin 64:159-182.

Hagström Å, Azam F, Andersson A, Wikner J, and Rassoulzadegan F. 1988. Microbial loop in an oligotrophic pelagic marine ecosystem: possible roles of cyanobacteria and nanoflagellates in the organic fluxes. Marine Ecology-Progress Series 49:171-178.

Hannides CCS, Landry MR, Benitez-Nelson CR, Styles RM, Montoya JP, and Karl DM. 2009. Export stoichiometry and migrant-mediated flux of phosphorus in the North Pacific Subtropical Gyre. Deep-Sea Research Part I-Oceanographic Research Papers 56:73-88. Hardy AC. 1935. The plankton of the South Georgia whaling grounds and adjacent waters, 19261927. Part II. The phytoplankton. Discovery Reports 11:39-87. 
780

781

782

783

784

785

786

787

788

789

790

791

792

793

794

795

796

797

798

799

800

801

802

803

804

805

806

807

808

809

810

811

812

813

814

815

816

817

818

819

820

821

822

823

824

825

826

Herbland A. 1983. Le maximum de chlorophylle dans l'Atlantique tropical oriental: description, écologie, interprétation. Océanogr trop 18:295-318.

Jenkins WJ, and Goldman JC. 1985. Seasonal oxygen cycling and primary production in the Sargasso Sea. Journal of Marine Research 43,:465-491.

Jenkinson IR. 1986. Halosphaera viridis, Ditylum brightwellii and other phytoplankton in the north-eastern North Atlantic in spring: sinking, rising and relative abundance. Ophelia 26:233-253.

Johnson KS, Riser SC, and Karl DM. 2010. Nitrate supply from deep to near-surface waters of the North Pacific subtropical gyre. Nature (London) 465:1062-1065.

Joseph L, and Villareal TA. 1998. Nitrate reductase activity as a measure of nitrogen incorporation in Rhizosolenia formosa (H. Peragallo): Internal nitrate and diel effects. Journal of Experimental Marine Biology and Ecology 229:159-176.

Joseph L, Villareal TA, and Lipschultz F. 1997. A high sensitivity nitrate reductase assay and its application to vertically migrating Rhizosolenia mats. Aquatic Microbial Ecology 12:95104.

Kamykowski D, Milligan EJ, and Reed RE. 1978. Relationships between geotaxis/phototaxis and diel vertical migration in autotrophic dinoflagellates. Journal of Plankton Research 20:1781-1796.

Karl DM, Bidigare RR, and Letelier RM. 2001. Long-term changes in plankton community structure and productivity in the North Pacific Subtropical Gyre: The domain shift hypothesis. Deep-Sea Research Part II-Topical Studies in Oceanography) 48:1449-1470.

Keeling CD, Brix H, and Gruber N. 2004. Seasonal and long-term dynamics of the upper ocean carbon cycle at Station ALOHA near Hawaii. Global Biogeochemical Cycles 18.

Kromkamp J, and Walsby AE. 1990. A computer model of buoyancy and vertical migration in cyanobacteria. Journal of Plankton Research 12:161-183.

Lännergren C. 1979. Buoyancy of natural populations of marine phytoplankton. Marine Biology (Berlin) 54:1-10.

Li BL, Karl DM, Letelier RM, and Church MJ. 2011. Size-dependent photosynthetic variability in the North Pacific Subtropical Gyre. Marine Ecology-Progress Series 440:27-40.

Lin S, and Carpenter EJ. 1995. Growth characteristics of marine phytoplankton determined by cell cycle proteins: the cell cycle of Ethmodiscus rex (Bacillariophceae) in the southwestern North Atlantic Ocean and Caribbean Sea. Journal of Phycology 31:778-785.

Lipschultz F, Bates NR, Carlson CA, and Hansell DA. 2002. New production in the Sargasso Sea: History and current status. Global Biogeochemical Cycles 16.

Lipschultz F, Zafiriou OC, and Ball LA. 1996. Seasonal fluctuations of nitrite concentrations in the deep ocean. Deep Sea Research Part II Topical Studies in Oceanography 43:403-419.

Lomas MW, Bates NR, Johnson RJ, Knap AH, Steinberg DK, and Carlson CA. 2013. Two decades and counting: 24-years of sustained open ocean biogeochemical measurements in the Sargasso Sea. Deep Sea Research Part II: Topical Studies in Oceanography 93:16-32.

Lomas MW, Rumbley CJ, and Glibert PM. 2000. Ammonium release by nitrogen sufficient diatoms in response to rapid increases in irradiance. Journal of Plankton Research 22:2351-2366.

Malmstrom RR, Coe A, Kettler GC, Martiny AC, Frias-Lopez J, Zinser ER, and Chisholm SW. 2010. Temporal dynamics of Prochlorococcus ecotypes in the Atlantic and Pacific oceans. Isme Journal 4:1252-1264.

Malone TC. 1980. Size-fractionated primary productivity of marine phytoplankton. In: Falkowski PG, ed. Primary Productivity in the Sea. New York: Plenum Press, 301-319. 
Maranon E, Holligan PM, Barciela R, Gonzalez N, Mourino B, Pazo MJ, and Varela M. 2001. Patterns of phytoplankton size structure and productivity in contrasting open-ocean environments. Marine Ecology-Progress Series 216:43-56.

Marino D, and Modigh M. 1981. An annotated check-list of planktonic diatoms from the Gulf of Naples. Marine Ecology 2:317-333.

Martinez L, Silver MW, King JM, and Alldredge AL. 1983. Nitrogen fixation by floating diatom mats: a source of new nitrogen to oligotrophic ocean waters. Science (Washington, DC) 221:152-154.

McGillicuddy DJ, Anderson LA, Bates NR, Bibby T, Buesseler KO, Carlson CA, Davis CS, Ewart C, Falkowski PG, Goldthwait SA et al. . 2007. Eddy/wind interactions stimulate extraordinary mid-ocean plankton blooms. Science (Washington, DC) 316:1021-1026.

McGillicuddy DJ, Jr., and Robinson AR. 1997. Eddy-induced nutrient supply and new production in the Sargasso Sea. Deep-Sea Research 44:1427-1450.

Meunier V, and Swift E. 1977. Observations on thecate swarmers of Pyrocystis species in laboratory culture: Pyrocystis fusiformis Wyville Thomson ex Murray and Pyrocystis pseudonoctiluca Wyville Thomson ex Murray (Dinococcales). Phycologia 16:359-365.

Michaels AF, Bates NR, Buesseler KO, Carlson CA, and Knap AH. 1994. Carbon-cycle imbalances in the Sargasso Sea. Nature (London) 372:537-540.

Montoya JP, Carpenter EJ, and Capone DG. 2002. Nitrogen fixation and nitrogen isotope abundances in zooplankton of the oligoltrophic North Atlantic. Limnology and Oceanography 47:1617-1628.

Montoya JP, Voss M, Kahler P, and Capone DG. 1996. A simple, high-precision, high-sensitivity tracer assay for N-2 fixation. Applied and Environmental Microbiology 62:986-993.

Montoya JP, Wiebe PH, and McCarthy JJ. 1992. Natural abundance of ${ }^{15} \mathrm{~N}$ in particulate nitrogen and zooplankton in the Gulf Stream region and warm-core ring 86A. Deep-Sea Research Part I-Oceanographic Research Papers 39:S363-S392.

Moore JK, and Villareal TA. 1996a. Buoyancy and growth characteristics of three positively buoyant marine diatoms. Marine Ecology-Progress Series 132:203-213.

Moore JK, and Villareal TA. 1996b. Buoyancy and growth characteristics of three positively buoyant marine diatoms. Marine Ecology Progress Series 132:203-213.

Moore JK, and Villareal TA. 1996c. Size-ascent rate relationships in positively buoyant marine diatoms. Limnology and Oceanography 41:1514-1520.

Moore LR, Post AF, Rocap G, and Chisholm SW. 2002. Utilization of different nitrogen sources by the marine cyanobacteria Prochlorococcus and Synechococcus. Limnology and Oceanography 47:989-996.

Nielsen ES. 1939. Über die vertikale Verbreitung der Phytoplanktonten im Meere. Internationale Revue der gesamten Hydrobiologie und Hydrographie 38:421-440.

Parke M, and den Hartog-Adams I. 1965. Three species of Halosphaera. Journal of the Marine Biological Association of the UK 45:537-557.

Pilskaln CH, Villareal TA, Dennett M, Darkangelo-Wood C, and Meadows G. 2005. High concentrations of marine snow and diatom algal mats in the North Pacific Subtropical Gyre: Implications for carbon and nitrogen cycles in the oligotrophic ocean. Deep-Sea Research Part I-Oceanographic Research Papers 52:2315-2332.

Platt T, Gallegos CL, and Harrison WG. 1980. Photoinhibition of photosynthesis in natural assemblages of marine phytoplankton. Journal of Marine Research 38:687-701.

Raimbault P, Garcia N, and Cerutti F. 2008. Distribution of inorganic and organic nutrients in the South Pacific Ocean - evidence for long-term accumulation of organic matter in nitrogendepleted waters. Biogeosciences 5:281-298. 
Raimbault P, Slawyk G, and Gentilhomme V. 1990. Direct measurements of nanomolar nitrate uptake by the marine diatom Phaeodactylum tricornutum (Bohlin). Implications or studies of oligotrophic ecosystems Hydrobiologia 207:311-318.

Richardson TL, Ciotti AM, Cullen JJ, and Villareal TA. 1996. Physiological and optical properties of Rhizosolenia formosa (Bacillariophyceae) in the context of open-ocean vertical migration. Journal of Phycology 32:741-757.

Richardson TL, Cullen JJ, Kelley DE, and Lewis MR. 1998. Potential contributions of vertically migrating Rhizosolenia to nutrient cycling and new production in the open ocean. Journal of Plankton Research 20:219-241.

Rivkin RB, and Lessard EJ. 1986. Photoadaptation of photosynthetic carbon uptake by solitary Radiolaria: comparisons with free-living phytoplankton. Deep-Sea Research Part IOceanographic Research Papers 33:1025-1038.

Rivkin RB, Swift E, Biggley WH, and Voytek MA. 1984. Growth and carbon uptake by natural populations of oceanic dinoflagellates Pyrocystis noctiluca and Pyrocystis fusiformis. Deep-Sea Research Part I-Oceanographic Research Papers 31:353-367.

Robinson D, Handley LL, and Scrimgeour CM. 1998. A theory for ${ }^{15} \mathrm{~N} /{ }^{14} \mathrm{~N}$ fractionation in nitrate-grown vascular plants. Planta 205:397-406.

Robison BH. 1984. Herbivory by the myctophid fish Ceratoscopelus warmingii. Marine Biology (Berlin) 84:119-123.

Scanlan DJ, Ostrowski M, Mazard S, Dufresne A, Garczarek L, Hess WR, Post AF, Hagemann M, Paulsen I, and Partensky F. 2009. Ecological genomics of marine picocyanobacteria. Microbiology and Molecular Biology Reviews 73:249-299.

Schmitz F. 1878. Halosphaera, eine neue Gattung grüner Algen aus dem Mittelmeer. Mittheilungen aus der Zoologischen Station zu Neapel 1:273-286.

Shipe RF, Brzezinski MA, Pilskaln C, and Villareal TA. 1999. Rhizosolenia mats: An overlooked source of silica production in the open sea. Limnology and Oceanography 44:1282-1292.

Sigman DM, Altabet MA, Michener R, McCorkle DC, Fry B, and Holmes RM. 1997. Natural abundance-level measurement of the nitrogen isotopic composition of oceanic nitrate: an adaptation of the ammonia diffusion method. Marine Chemistry 57:227-242.

Singler HR, and Villareal TA. 2005. Nitrogen inputs into the euphotic zone by vertically migrating Rhizosolenia mats. Journal of Plankton Research 27:545-556.

Smayda TJ. 1970. The suspension and sinking of phytoplankton in the sea. Oceanography and Marine Biology Annual Review 8:353-414.

Smayda TJ, and Boleyn BJ. 1966. Experimental observations on the flotation of marine diatoms. II. Skeletonema costatum and Rhizosolenia setigera. Limnology and Oceanography 11:18-34.

Smetacek VS. 1985. The role of sinking in diatom life-history cycles: ecological, evolutionary and geological significance. Marine Biology (Berlin) 84:239-251.

Sournia A. 1982. Is there a shade flora in the marine plankton? Journal of Plankton Research 4:391-399.

Steinberg DK, Carlson CA, Bates NR, Goldthwait SA, Madin LP, and Michaels AF. 2000. Zooplankton vertical migration and the active transport of dissolved organic and inorganic carbon in the Sargasso Sea. Deep-Sea Research Part I-Oceanographic Research Papers 47:137-158.

Steinberg DK, Goldthwait SA, and Hansell DA. 2002. Zooplankton vertical migration and the active transport of dissolved organic and inorganic nitrogen in the Sargasso Sea. DeepSea Research Part I-Oceanographic Research Papers 49:1445-1461. 
Steinberg DK, Van Mooy BAS, Buesseler KO, Boyd PW, Kobari T, and Karl DM. 2008. Bacterial vs. zooplankton control of sinking particle flux in the ocean's twilight zone. Limnology and Oceanography 53:1327-1338.

Sukhanova IN. 1973. Vertical distribution of some peridinians in the equatorial Pacific Ocean. In: Vinogradov ME, ed. Life activities of pelagic communities in the ocean. Israeli Program Scientific Translation. Jerusalem., 210-217.

Sukhanova IN, and Rudyakov YA. 1973. Population composition and vertical distribution of Pyrocystis pseudonoctiluca (W. Thomson) in the western equatorial Pacific. In: Vinogradov ME, ed. Life activities of pelagic communities in the ocean. Israeli Program Scientific Translation. Jerusalem., 218-228.

Sverdrup HU, Johnson MW, and Fleming RH. 1942. The Oceans. Their Physics, chemistry, and general biology. Englewood Cliffs: Prentice-Hall.

Swift E. 1973. The marine diatom Ethmodiscus rex: its morphology and occurrence in the plankton of the Sargasso Sea. Journal of Phycology 2:456-460.

Swift E, and Durbin EG. 1971. Similarities in asexual reproduction of oceanic dinoflagellates, Pyrocystis fusiformis, Pyrocystis lunula, and Pyrocystis noctiluca. Journal of Phycology 7:89-\&.

Swift E, Stuart M, and Meunier V. 1976a. The in situ growth rates of some deep-living oceanic dinoflagellates: Pyrocystis fusiformis and Pyrocystis noctiluca. Limnology and Oceanography 21:418-426.

Swift E, Stuart M, and Meunier V. 1976b. A note on the maturation of reprodcutive bodies of Pyrocystis spp. and its implication for in situ growth rate studies. Deep-Sea Research Part I-Oceanographic Research Papers 23:239-243.

Ter Steege MW, Stulen I, Wiersema PK, Posthumus F, and Vaalburg W. 1999. Efficiency of nitrate uptake in spinach: impact of external nitrate concentration and relative growth rate on nitrate influx and efflux. Plant and Soil 208:125-134.

Venrick EL. 1982. Phytoplankton in an oligotrophic ocean: Observations and questions. Ecological Monographs 52:129-154.

Venrick EL. 1988. The vertical distributions of chlorophyll and phytoplankton species in the North Pacific central environment. Journal of Plankton Research 10:987-998.

Venrick EL. 1990. Phytoplankton in an oligotrophic ocean: species structure and interannual variability. Ecology 71:1547-1563.

Venrick EL. 1999. Phytoplankton species structure in the central North Pacific, 1973-1996: variability and persistence. Journal of Plankton Research 21:1029-1042.

Villareal TA. 1988. Positive buoyancy in the oceanic diatom_Rhizosolenia debyana H. Peragallo. Deep-Sea Research Part I-Oceanographic Research Papers 35:1037-1045.

Villareal TA. 1993. Abundance of the giant diatom Ethmodiscus in the southwest Atlantic Ocean and central Pacific gyre. Diatom Research 8:171-177.

Villareal TA, Altabet MA, and Culver-Rymsza K. 1993. Nitrogen transport by vertically migrating diatoms mats in the North Pacific Ocean. Nature (London) 363:709-712.

Villareal TA, and Carpenter EJ. 1989. Nitrogen-fixation, suspension characteristics and chemical composition of Rhizosolenia mats in the central North Pacific Gyre. Biological Oceanography 6:327-345.

Villareal TA, and Carpenter EJ. 1994. Chemical composition and photosynthetic characteristics of Ethmodiscus rex (Bacillariophyceae): Evidence for vertical migration. Journal of Phycology 30:1-8.

Villareal TA, Joseph L, Brzezinski MA, Shipe RF, Lipschultz F, and Altabet MA. 1999a. Biological and chemical characteristics of the giant diatom Ethmodiscus (Bacillariophyceae) in the central North Pacific gyre. Journal of Phycology 35:896-902. 
Villareal TA, and Lipschultz F. 1995. Internal nitrate concentrations in single cells of large phytoplankton from the Sargasso Sea. Journal of Phycology 31:689-696.

Villareal TA, McKay RML, Al-Rshaidat MMD, Boyanapalli R, and Sherrell RM. 2007. Compositional and fluorescence characteristics of the giant diatom Ethmodiscus along a $3000 \mathrm{~km}$ transect (28 degrees N) in the central North Pacific gyre. Deep-Sea Research Part I-Oceanographic Research Papers 54:1273-1288.

Villareal TA, Pilskaln C, Brzezinski M, Lipschultz F, Dennett M, and Gardner GB. 1999b. Upward transport of oceanic nitrate by migrating diatom mats. Nature (London) 397:423425.

Villareal TA, Woods S, Moore JK, and Culver-Rymsza K. 1996. Vertical migration of Rhizosolenia mats and their significance to $\mathrm{NO}_{3}{ }^{-}$fluxes in the central north Pacific gyre. Journal of Plankton Research 18:1103-1121.

Waite A, Fisher A, Thompson PA, and Harrison PJ. 1997. Sinking rate versus cell volume relationships illuminate sinking rate control mechanisms in marine diatoms. Marine Ecology Progress Series 157:97-108.

Waite A, and Harrison PJ. 1992. Role of sinking and ascent during sexual reproduction in the marine diatom Ditylum brightwellii. Marine Ecology-Progress Series 87:113-122.

Waite AM, and Nodder SD. 2001. The effect of in situ iron addition on the sinking rates and export flux of Southern Ocean diatoms. Deep-Sea Research Part Ii-Topical Studies in Oceanography 48:2635-2654.

Wallich GC. 1858. On microscopic objects collected in India, \& c. Transactions of the Microscopical Society of London 6:81-87.

Wallich GC. 1860. On the siliceous organisms found in the digestive cavities of the salpae, and their relation to the flint nodules of the chalk formation. Quarterly Journal of Microscopical Science 8:36-55.

Ward BB. 2008. Nitrification in Marine Systems. In: Capone DG, Bronk DA, Mulholland MR, and Carpenter EJ, eds. Nitrogen in the Marine Environment, 2nd Edition: Elsevier Academic Press Inc, 525 B Street, Suite 1900, San Diego, Ca 92101-4495 USA, 199-261.

Wiebe PH, Remsen CC, and Vaccaro RF. 1974. Halosphaera viridis in the Mediterranean Sea: size range, vertical distribution, and potential energy source for deep-sea benthos. Deep Sea Research Part I Oceanographic Research Papers 21:657-667.

Woods S, and Villareal TA. 2008. Intracellular ion concentrations and cell sap density in positively buoyant oceanic phytoplankton. Nova Hedwigia:131-145.

Wu J, Sunda W, Boyle EA, and Karl DM. 2000. Phosphate depletion in the Western North Atlantic Ocean. Science (Washington) 289:759-762.

Wyman M, and Bird C. 2007. Lack of control of nitrite assimilation by ammonium in an oceanic picocyanobacterium, Synechococcus sp strain WH 8103. Applied and Environmental Microbiology 73:3028-3033.

Yoder JA, Ackleson S, and Balch WM. 1994. A line in the sea. Nature (London) 371:689-692. 


\section{Table $\mathbf{1}_{\text {(on next page) }}$}

$\mathrm{N}$ flux across the nutricline calculated from video plankton recorder (VPR) and diverbased observations made during 2003.

Table 1. $\mathrm{N}$ flux across the nutricline calculated from video plankton recorder (VPR) and diverbased observations made during 2003. Flux calculations assumed 0.19 and $2.5 \mu \mathrm{mol} \mathrm{N} \mathrm{mat}{ }^{-1}$ ( Villareal et al. 1999b) for small and large mats, respectively, and a specific rate increase of $0.14 \mathrm{~d}^{-1}$ ( Richardson et al. 1998 ) Diver and VPR estimates are added due to the nonoverlapping nature of the abundance estimates. These estimates are supplemented with contributions to upward nitrate flux from other (non-Rhizosolenia mat) migrating phytoplankton. Doubling time reflects the time required to migrate to depth, acquire nutrients, return to the surface and divide and is based on direct measurement or best available information (citations may be found in the text section on the individual taxon). 
Rhizosolenia mats

Integrated mats

(mats $\mathrm{m}^{-2}$ )

Sta. 5 Sta. 6 Sta. $7 \quad$ Sta. 12a $\quad$ Sta. 12b

Divers $(0-20 \mathrm{~m})$

$\operatorname{VPR}(0-20 \mathrm{~m})$

$\begin{array}{llllll}26 & 3 & 3 & 6 & 6.4\end{array}$

VPR $(0-150 \mathrm{~m})$

$\begin{array}{lllll}188 & 38 & 3938 & 38 & 300\end{array}$

VPR:Diver $(0-20)$

$2,475 \quad 188 \quad 6,562 \quad 17,062 \quad 16,612$

$\begin{array}{lllll}7 & 13 & 1313 & 6 & 47\end{array}$

$\mathrm{N}$ flux $\left(\mu \mathrm{mol} \mathrm{N} \mathrm{m} \mathrm{m}^{-2} \mathrm{~d}^{-1}\right)$

$\begin{array}{llllll}\text { Diver-based N flux } & 8.9 & 1 & 1 & 2 & 2\end{array}$

\begin{tabular}{llllll} 
VPR-based N flux & 64 & 5 & 170 & 442 & 430 \\
\hline TOTAL (Diver+VPR) & 73 & 6 & 171 & 444 & 432
\end{tabular}

Other Migrating Phytoplankton

\begin{tabular}{|c|c|c|c|c|}
\hline Taxon & $\begin{array}{c}\text { Abundance } \\
0-100 \mathrm{~m}^{\left(\text {cells } \mathrm{m}^{-3}\right)}\end{array}$ & $\begin{array}{l}\mathrm{N} \text { doubling } \\
\text { time rate } \\
\left(\mathrm{d}^{-1}\right)\end{array}$ & $\begin{array}{c}\text { nmol N } \\
\text { cell }^{-1}\end{array}$ & $\begin{array}{c}\mathrm{N} \text { flux } \\
\mu \underset{1}{\operatorname{mol} \mathrm{N} \mathrm{d}^{-}}\end{array}$ \\
\hline $\begin{array}{l}\text { Ethmodiscus } \\
\text { spp. } \\
\text { Halosphaera }\end{array}$ & 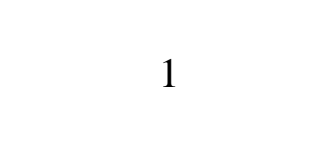 & 0.09 & 29 & 3.2 \\
\hline spp. & 200 & 0.1 & 1.5 & 33.2 \\
\hline $\begin{array}{l}\text { Pyrocystis spp. } \\
\text { Rhizosolenia }\end{array}$ & 200 & 0.06 & 0.8 & 17.0 \\
\hline spp. & 50 & 0.14 & 1.6 & 9.2 \\
\hline
\end{tabular}




\section{Table 2 (on next page)}

Compositional values of Rhizosolenia mats from 2002-2003. These data span from apprpoximately $145^{\circ} \mathrm{W}$ to $178^{\circ} \mathrm{E}$.

Table 2. Compositional values of Rhizosolenia mats from 2002-2003. These data span from apprpoximately $145^{\circ} \mathrm{W}$ to $178^{\circ} \mathrm{E}$. 
Year

ascending

sinking $\delta^{15} \mathrm{~N}$

$1.38 \pm 0.6(30)$ $3.6 \pm 0.8$

(5)
2002

$\begin{array}{cc}2002 & \\ \delta^{13} \mathrm{C} & \mathrm{C}: \mathrm{N} \\ & \\ -30.41 \pm 0.45 & 8.0 \pm 0.5 \\ (30) & (51) \\ -30.41 \pm 0.22 & 12.3 \pm 1.8 \\ (5) & (18)\end{array}$

$\delta^{15} \mathrm{~N}$
$2.5 \pm 0.4$
$(95)$
$3.5 \pm 0.5$
$(34)$

\begin{tabular}{cc}
\multicolumn{2}{c}{2003} \\
$\delta^{13} \mathrm{C}$ & $\mathrm{C}: \mathrm{N}$ \\
& \\
$-30.71 \pm .30$ & \\
$(92)$ & $6.9 \pm 1.6(92)$ \\
$-30.80 \pm .80$ & $12.3 \pm 0.8$ \\
$(34)$ & $(34)$
\end{tabular}




\section{Figure 1}

Fig. 1. Rhizosolenia mats.

Fig. 1. Rhizosolenia mats. All scale bars are approximate. A. Orientation view of Rhizosolenia mats in-situ. Numerous mats are evident. Station 13,5 July $2002,30.44^{\circ} \mathrm{N}$ $145.45^{\circ}$ W B. Individual Rhizosolenia mat. Station 13,5 July $2002,30.43^{\circ} \mathrm{N} 145.45^{\circ} \mathrm{W}$ C. micrograph of individual mat Rhizosolenia chains. Brown regions are the nuclear mass and protoplasm of individual chains. Some cell lysis is evident due to the pressure of the cover slip. Sta. 13, 7 Sept. $199231.38^{\circ} \mathrm{N} 149.89^{\circ} \mathrm{W}$.
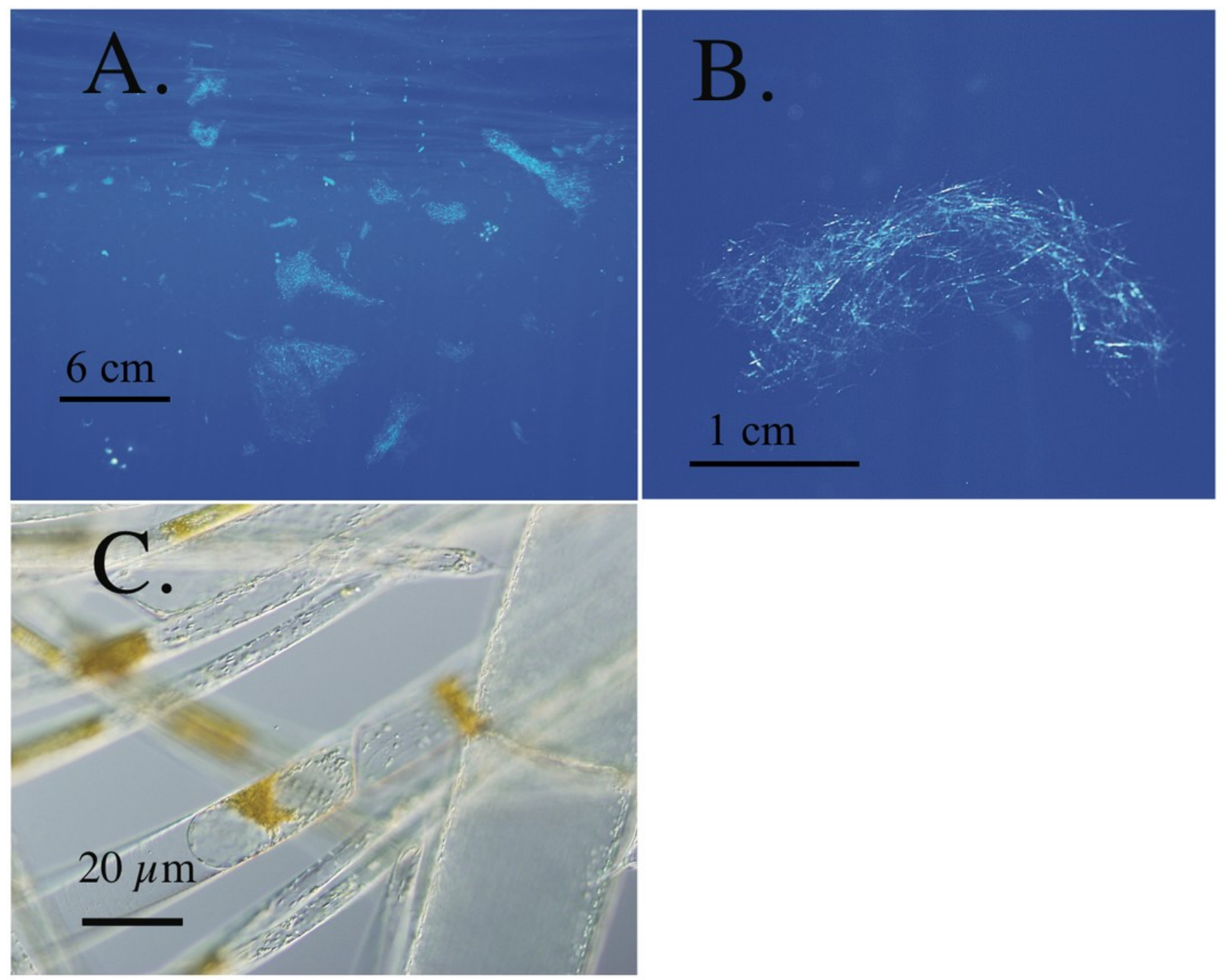


\section{Figure 2}

Cruise track map of sampling locations.

Fig. 2. Cruise track map of sampling locations. Cruises RNBT17WT (Mar/April 1989), W9208C (Aug. 1992), PacMat (May/June. 1993), RoMP95 (Jun./Aug. 1995), RoMP96 (Jun./Aug. 1996), RoMP2002 (Jun. 2002), RoMP2003 (Aug./Sept. 2003), POOB2008 (Jul. 2008). Data has partially or completely presented in: RNBT17WT (Villareal \& Carpenter 1989), W9208C \& PacMat (Villareal et al. 1993; Villareal et al. 1996), RoMP95 \& RoMP96 (Pilskaln et al. 2005; Shipe et al. 1999; Villareal et al. 1999b), RoMP2002, RoMP2003 \& POOB2008 (this report).

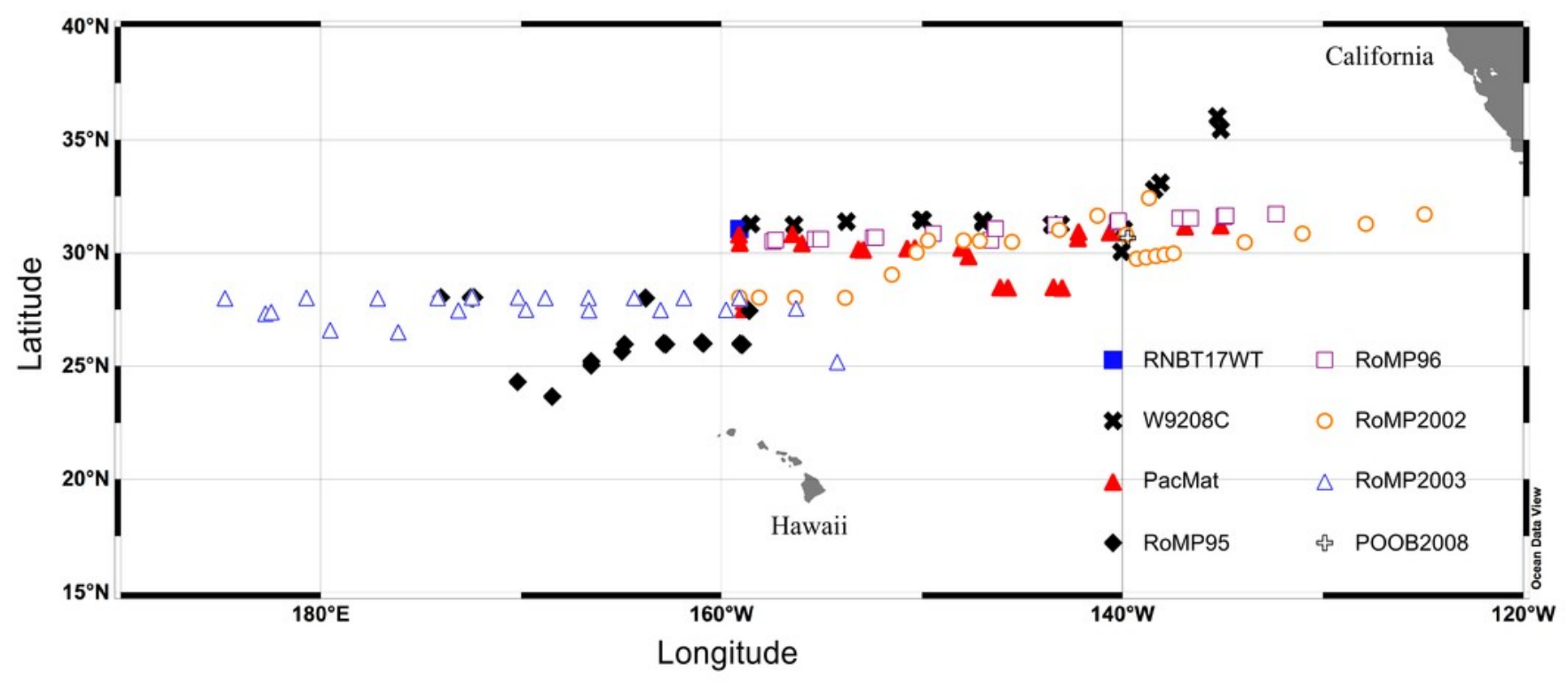




\section{Figure 3}

Vertical distribution and abundance of Rhizosolenia mats observed by divers.

Fig. 3. Vertical distribution and abundance of Rhizosolenia mats observed by divers.

Abundance was estimated visually using a metered frame (Villareal et al. 1996). The 1982 data are from Alldredge and Silver (1982). The remaining data (67 stations) are from cruises summarized in Fig. 2. For purposes of plotting, a zero abundance at a depth was recorded as 0.01 mats $^{-3}$. Integrated mat abundance used actual values collected. No abundance data were available from POOB2008. 


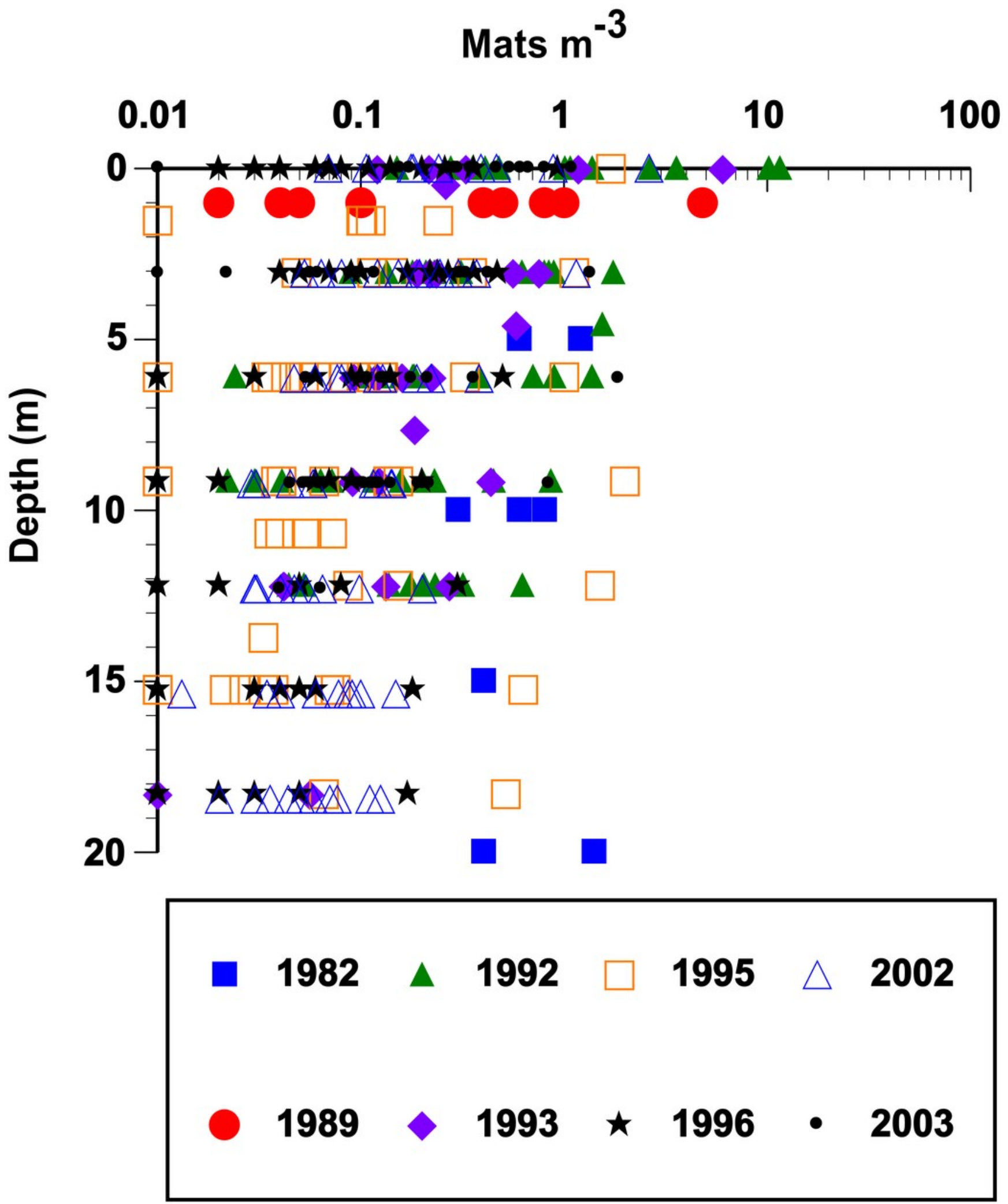




\section{Figure 4}

Rhizosolenia mat integrated abundance

Fig. 4. Rhizosolenia mat integrated abundance. Diver-collected abundance in the upper 60 m. Data are from 6 cruises spanning 1992-2003 and literature sources ( Alldredge \& Silver 1982 ; Martinez et al. 1983 ). Total number of stations, $n=96$. Filled squares indicate stations where mats were observed but not quantified. The A is Sta. ALOHA of the Hawai'i Ocean Time-Series (HOT).

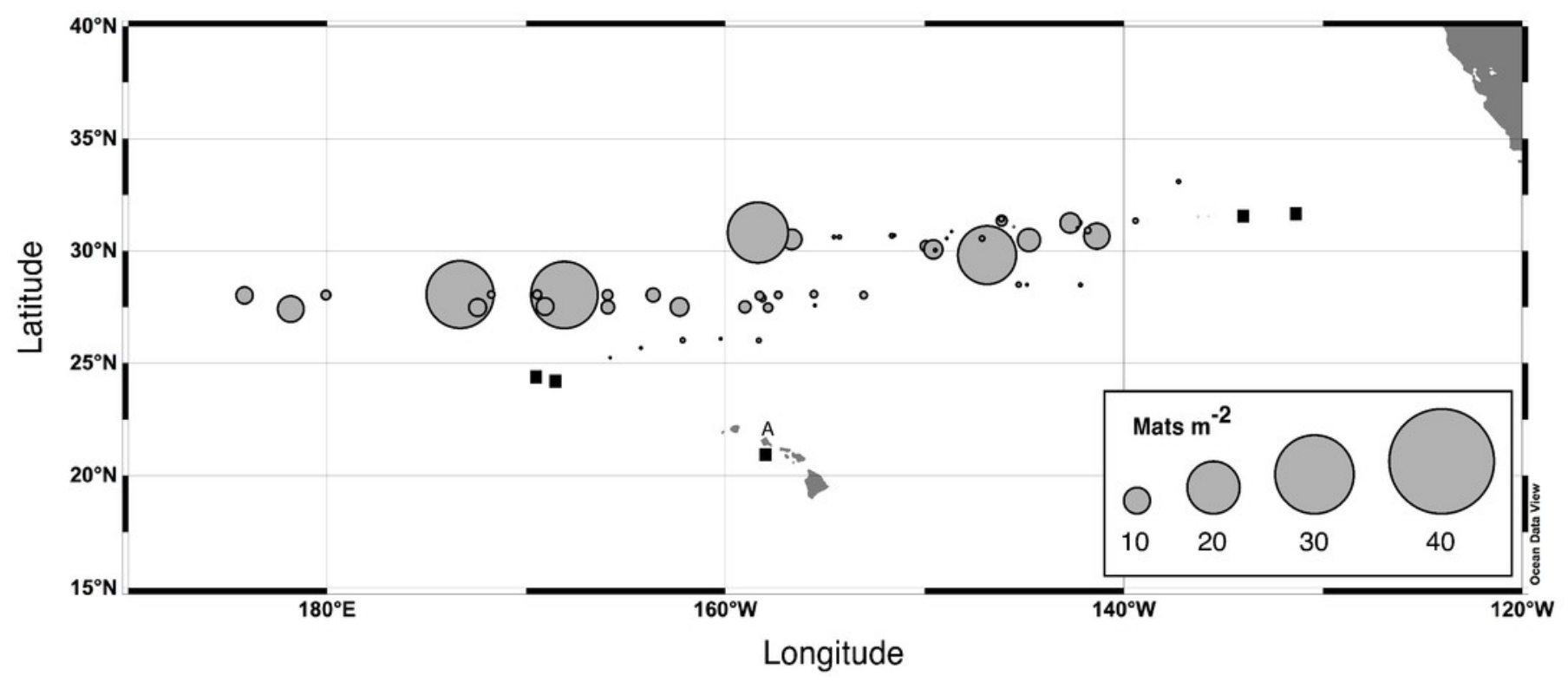




\section{Figure 5}

Vertical distribution of Rhizosolenia mats observed by the video plankton recorder. Data are from Aug./Sept. 2003.

Fig. 5. Vertical distribution of Rhizosolenia mats observed by the video plankton recorder. Data are from Aug./Sept. 2003 (RoMP2003). Station positions are given in the figure. Data is for all sizes of mats observed by the VPR.
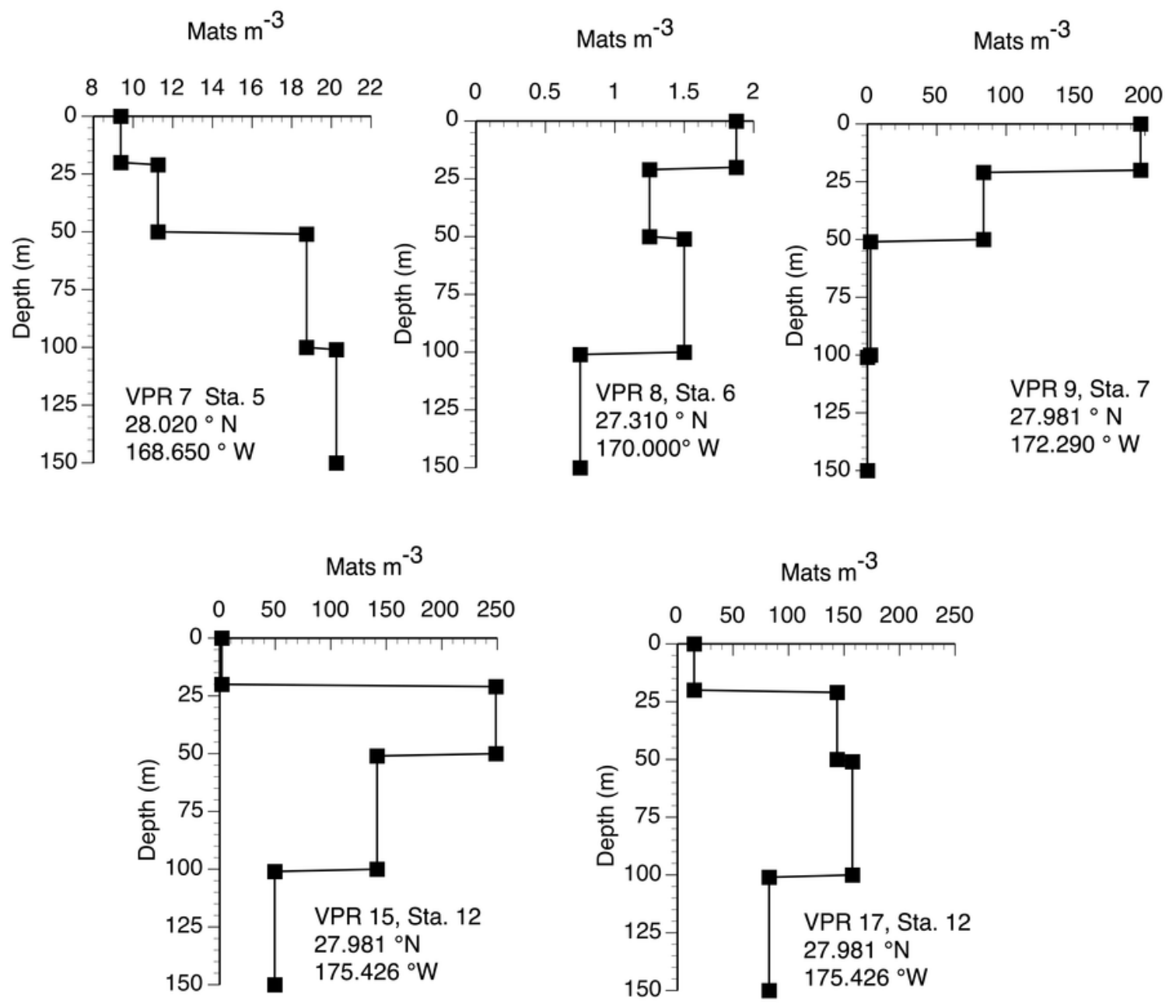


\section{Figure 6}

Histogram of Rhizosolenia mat $\delta^{15} \mathrm{~N}$. ( $\left.\mathrm{n}=170\right)$.

Fig. 6. Histogram of Rhizosolenia mat $\delta^{15} \mathrm{~N}$. ( $\left.n=170\right)$. Bins are 2 per mil with the lower value included in the bin and the higher value representing the upper limit. Ascending mats were statistically lighter $(2.17 \pm 0.32$ per mil, $n=125)$ than descending mats $(3.53 \pm 0.39$ per mil, $\mathrm{n}=45$ ). Error bars are $95 \%$ confidence intervals. Samples were collected at regular intervals on RoMP2002 and RoMP2003 (Fig. 2)
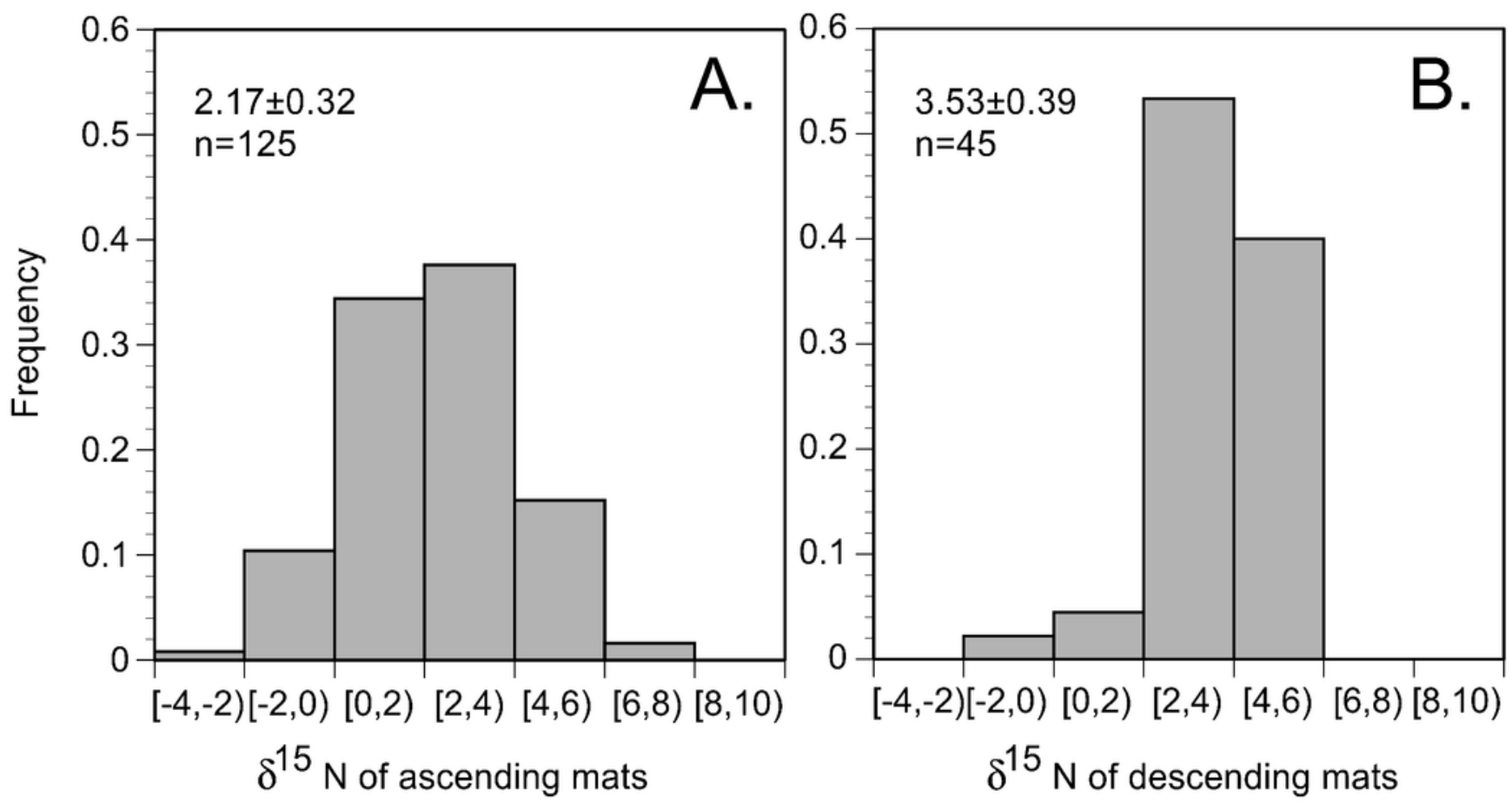


\section{Figure 7}

Particulate $\delta^{15} \mathrm{~N}$ and nitrate $\delta^{15} \mathrm{~N}$ of the sampled areas in the Pacific Ocean

Fig. 7. Particulate $\delta^{15} \mathrm{~N}$ and nitrate $\delta^{15} \mathrm{~N}$ of the sampled areas in the Pacific Ocean.

Suspended particulate data (open symbols) are from the 2002 cruise, pooled from Sta. 1 $\left(22.197^{\circ} \mathrm{N} 157.960^{\circ} \mathrm{W}\right), 5\left(28.008^{\circ} \mathrm{N} 158.019^{\circ} \mathrm{W}\right), 7\left(28.000^{\circ} \mathrm{N} 153.736^{\circ} \mathrm{W}\right)$ and 10 $\left(30.504^{\circ} \mathrm{N} 149.615^{\circ} \mathrm{W}\right)$. Rhizosolenia mat $\delta^{15} \mathrm{~N}$ is averaged (box and whiskers) over all cruises ( $\pm 95 \%$ C.I.). Open symbols are suspended particulate material $\delta^{15} \mathrm{~N}$, large solid symbols are dissolved $\mathrm{NO}_{3}{ }^{-} \delta^{15} \mathrm{~N}$, small filled squares are the dissolved $\mathrm{NO}_{3}{ }^{-}$concentration (2003 stations). Red "X" are from Casciotti et al. (2008) at Station ALOHA. Black "X" are from the 2002 stations.

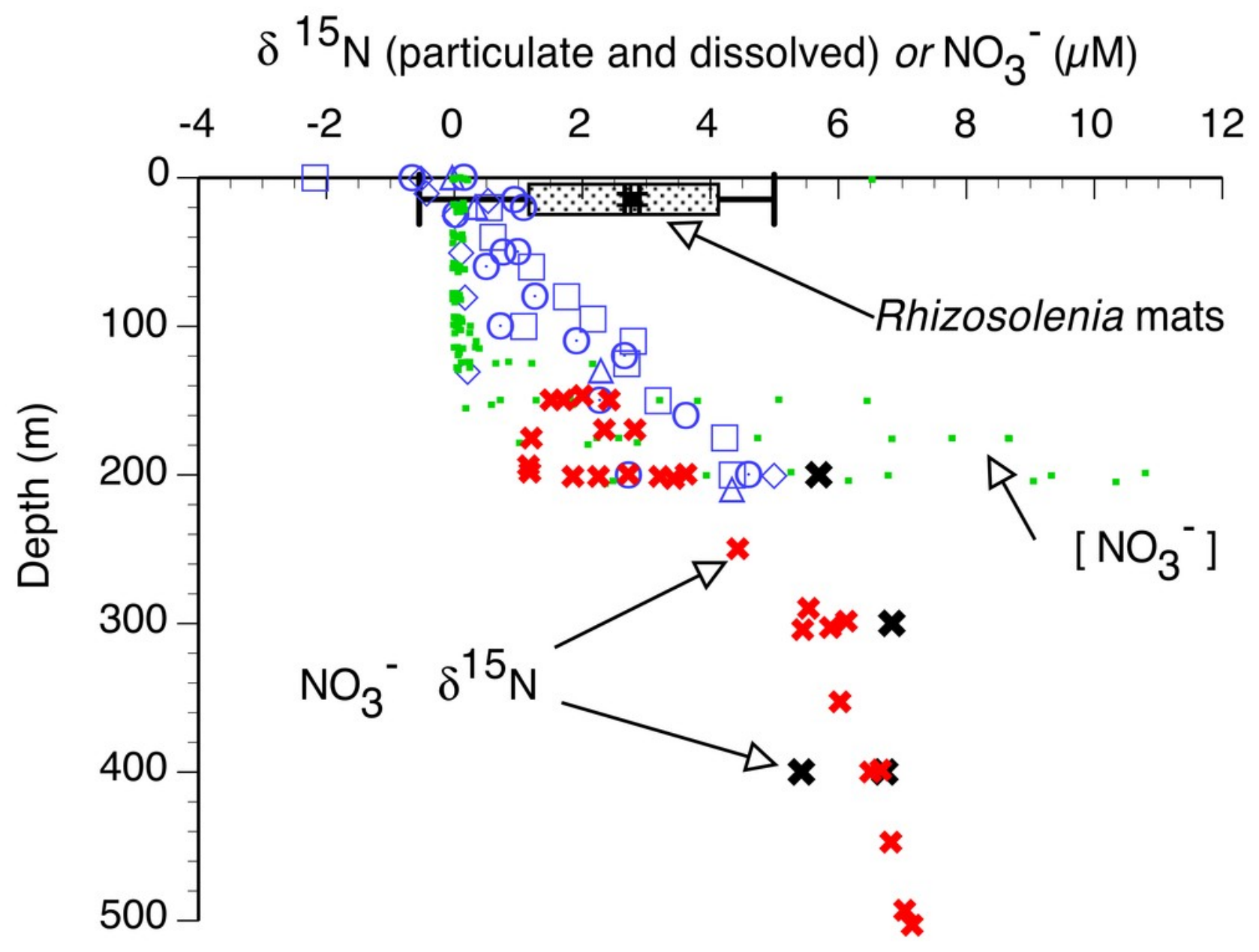




\section{Figure 8}

Conceptual model of vertical migration in Rhizosolenia mats and other giant phytoplankton.

Fig. 8. Conceptual model of vertical migration in Rhizosolenia mats and other giant phytoplankton. In this simplified representation, depth intervals are given in only general terms to allow for significant life history variations in the various taxa noted in the text.. Data soures: rate measurements supporting time at depth (Richardson et al. 1996), surface photosynthetic rates (Villareal et al. 1996), $\mathrm{NO}_{3}{ }^{-}$assimilation (Joseph et al. 1997), ascent rates (Moore \& Villareal 1996a; Moore \& Villareal 1996c).

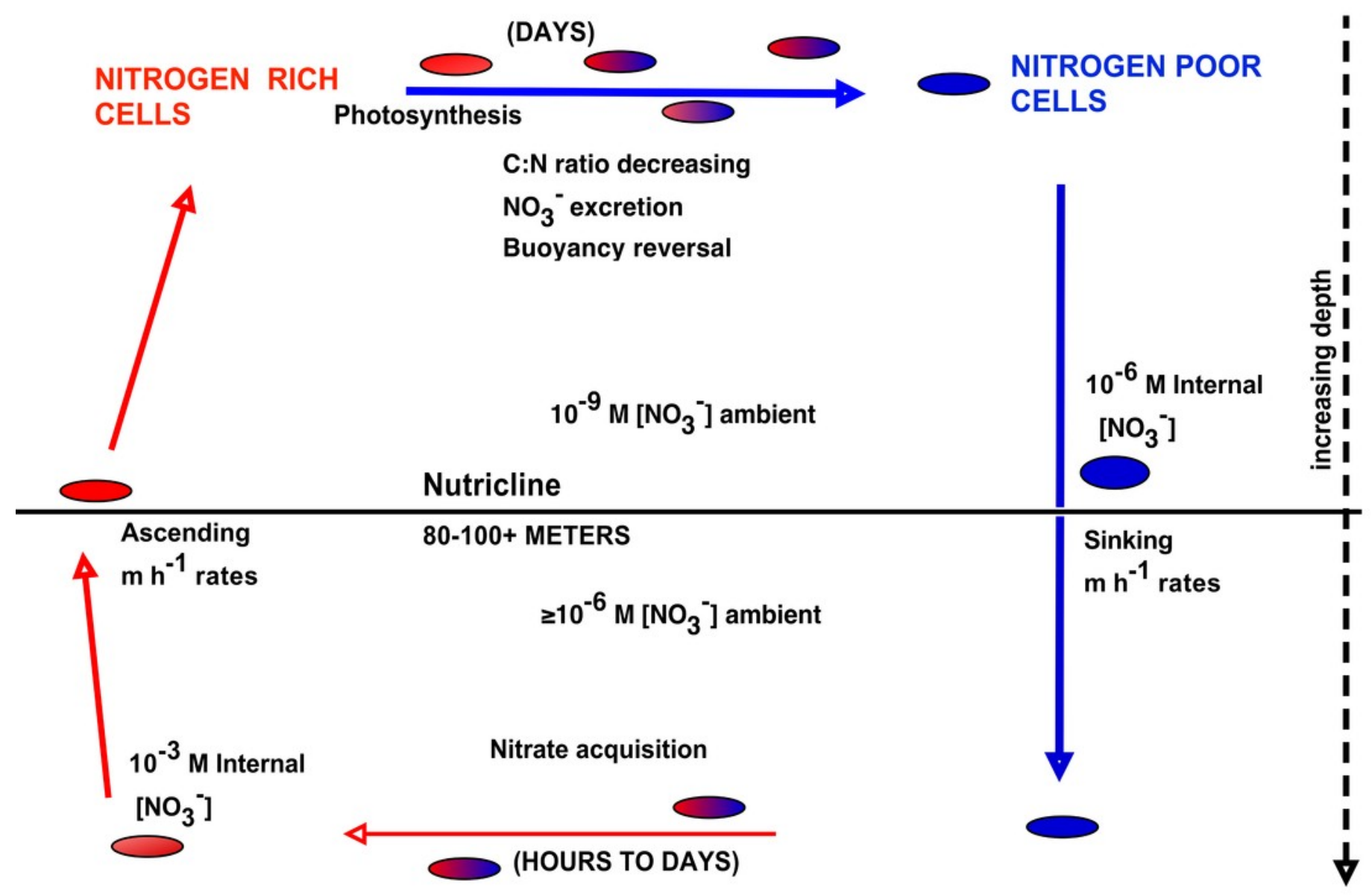

